\title{
Fold belts and sedimentary basins of the Eurasian Arctic
}

\author{
Sergey S. Drachev ${ }^{1}$
}

Received: 28 September 2015/Accepted: 21 October 2015/Published online: 30 March 2016

(C) Springer-Verlag Berlin Heidelberg 2016

\begin{abstract}
The vast Eurasian Arctic epicontinental shelf and adjoining mainland has a very complex structure and tectonic history as a result of a series of continent-continent collisions, accretion of terranes and crustal extension phases during Neoproterozoic and Phanerozoic times. Significant parts of major Eurasian fold belts extend far north into the Arctic below thick infill of post-orogenic sedimentary basins, where their architecture remains highly disputed. Large Eurasian Arctic sedimentary basins formed as a result of orogenic collapse, back-arc extension, or intracontinental extension associated with the breakup of the Laurussia, Laurasia, Pangea and Eurasia supercontinents. There are over 40 sedimentary basins of variable age and genesis which are thought to bear significant undiscovered hydrocarbon resources in the region. This article reviews the current state-of-knowledge of Eurasian Arctic tectonics and highlights questions that remain to be addressed. The overall focus is on the Russian sector of the Arctic being less known to a broad geoscience community.
\end{abstract}

Keywords Fold belt · Orogen - Terrane - Sedimentary basin · Rift

\section{Introduction}

Arctic is a unique region of our planet in many respects including its geology. In a relatively confined area north of the Arctic Circle there is a great variety of tectonic crustal domains

Sergey S. Drachev

sdrachev@gmail.com

1 ArcGeoLink Ltd., 48 Tupwood Gardens, Caterham, Surrey CR3 6EW, UK and overlying sedimentary accumulations ranging from the pre-Neoproterozoic North America, Baltica and Siberia cratons, to Cretaceous and Cenozoic Amerasia and Eurasia oceanic basins. In between, there is a series of Neoproterozoic and Phanerozoic fold belts extending into the Arctic shelves and forming the tectonic basement of large offshore sedimentary basins. The latter are considered the last hydrocarbon frontier and estimated to hold as much as 90 billion barrels of undiscovered recoverable oil and 1670 trillion cubic feet of recoverable natural gas [39] of hydrocarbon resources.

The present-day Arctic has formed due to the northerly directed drift of continents, which resulted in creation of the Pangea Supercontinent in Permian time, and following disintegration of this supercontinent during Mesozoic and Cenozoic time [85, 145]. This geological history is recorded in the rocks of the Arctic fold belts and sedimentary basins. Geological data from Arctic continental margins are also a significant source of information about processes that formed the deep water basins and ridges of the High Arctic, especially true for the Amerasia Basin where datasets remain scarce.

The Eurasian Arctic is dominated by fold belts that extend offshore under thick sedimentary accumulations and consequently are poorly understood. There have been several overviews published relatively recently attempting to summarize the geology of parts of the Arctic [26, 49, 52, 115, 120]. This paper focusses on the Russian Arctic, where new data allows for an improved understanding of the tectonics of a vast offshore region.

\section{Fold belts}

The Arctic fold belts are all products of major postPalaeoproterozoic orogenic events, i.e., Neoproterozoic, early Palaeozoic (Caledonian), late Palaeozoic (analogues 
of Hercynian orogeny in Central Europe), and late Mesozoic and Cenozoic orogenies. Most of these fold belts are located in the Eurasian sector. For the purpose of this overview, Mesoproterozoic fold belts are not differentiated from the older rocks of the cratons and, therefore, are not characterized below.

\section{Neoproterozoic Timanian fold belt (TFB)}

The TFB surrounds the Baltica Craton to the NE and E (present-day coordinates). It is locally exposed in the Timan Range, on Kanin, Rybachii and Varanger peninsulas (Figs. 1, 2), while a major part of it is buried under thick sediments of the Timan-Pechora Platform (basin) where Precambrian rocks are documented by petroleum exploration wells at $0.5-4.5 \mathrm{~km}$ depth. The eastern flank of the TFB is reworked by Late Palaeozoic Uralian deformation (see Uralian Fold Belt below). Detailed information about geology and history of Timanides is summarized by Gee and Pease [42], Kuznetsov et al. [80-83], Pease et al. [119], Andreichev [3].

The TFB consists of two first-order tectonic elements (from west to east): the Timan and Bol'shezemel'sk domains separated by the Pripecho-Ilych-Chikshinsk Suture. The latter is inferred to mark the NE limit of the Baltican crustal domain [65].

The Timan domain represents a proximal to Baltica Cryogenian passive continental margin dominated by weakly to moderately metamorphosed and deformed shelfal siliciclastic rocks. It is separated from the Baltica Craton by the West Timanian Thrust. The eastern flank of the domain (Izym Block in the Russian literature) is dominated by distal deep-water slate rocks [3].

The Bol'shezemel'sk domain is mostly composed of metamorphosed and intensely deformed Neoproterozoic volcanic and volcaniclastic rocks of basalt-andesitedacite-rhyolite series, mafic intrusives and bodies of ultramafic rocks - fragments of an ophiolite complex [6, 22]. It is interpreted to represent a fragment of a magmatic island arc possibly developed on an oceanic lithosphere [3] between c. 700-560 Ma [81]. The central part of the Bol'shezemel'sk domain is occupied by a smaller block known as the Khoreiversk Massif, with sialic crustal characteristics indicated from geophysical data [3]. The massif is dominated by volcanic and volcaniclastic calc-alkaline rocks with interbeds of siliciclastic rocks and is capped by an uppermost Neoproterozoic to Cambrian continental molasse. Another similar crustal block, the Kolguev Massif, is inferred beneath the SW Pechora Sea. Both of these massifs are interpreted to represent microcontinentsfragments of an older Pretimanian crust accreted to the Baltican margin in Neoptroterozoic time [3, 6].

Based on the isotopic age of collisional granitoids and detrital zircon ages from syn- and post-collisional formations, the TFB formed between c. 560-510 Ma [8183]. The cause of the Timanian orogenesis is disputed. Some authors believe that it was a result of island-arc (Cadomian island-arc [139] accretion to the Baltica margin accommodated by closure of an oceanic basin called the Pechora [132], Palaeo-Asian [66] or Proto-Uralian [81] ocean, which may have existed between 850-650 Ma [3]. Other authors argue that the TFB formed as a result of a collision between Baltica and a hypothetical continent Barentsia, or Arctida [81-83].

The TFB can be projected as far northwest as the Varanger and Rybachi peninsulas, where the Neoproterozoic passive margin rocks are exposed. To the north, it can be traced in the magnetic field under the Pechora Sea up to the southern slope of the East Barents Megatrough (see below). The Timanian basement is inferred to underlie Southern Island of the Novaya Zemlya Archipelago [17, 116], and the North Kara Province, which is also referred to as a North Kara Terrane or microcontinent [29, 88-90, 95].

\section{Early Palaeozoic Caledonian fold belt (CFB)}

The CFB fold belt is a large tectonic feature dominating northernmost Europe. It extends for almost $3000 \mathrm{~km}$ from Northern Ireland to the central Barents Sea where its offshore continuation is obscured by mid-Palaeozoic crustal extension and is hidden below a thick Devonian to Cenozoic sedimentary cover. The Norwegian sector of the CFB is known as the Scandinavian Caledonides [19, 41]. It extends as far north as Spitzbergen and can be projected further north to the Canadian Arctic (Gudlaugsson et al. [50, 11, 61, 115]). The CFB formed due to the closure of the early Palaeozoic Iapetus Ocean and Laurentia/Baltica collision beginning in the Silurian and continuing into the Devonian. It represents a classical example of an intracontinental bi-vergent collisional system. The NW part (present-day coordinates) of the fold belt has been rifted away from Baltica during the opening of the NorwegianGreenland oceanic basin in Cenozoic time and is known as East Greenland Caledonides.

The Scandinavian Caledonides are composed of a set of allochthonous units, or nappe complexes: telescoped fragments of the pre-collisional Baltoscandian margin, fragments of magmatic arc complexes and crustal blocks (terranes) of non-Baltic affinity, ophiolites and rocks of possible Laurentia affinity [19, 40]. These used to be interpreted as organized into a simple bottom-up succession of four allochthons: (1) Lower Allochthon, (2) Middle Allochthon, (3) Upper Allochthon, and (4) Uppermost Allochthon [40]. Recently, with the accumulation of modern geochronological data, a revised approach has been developed [19 and references therein]. Along-strike 


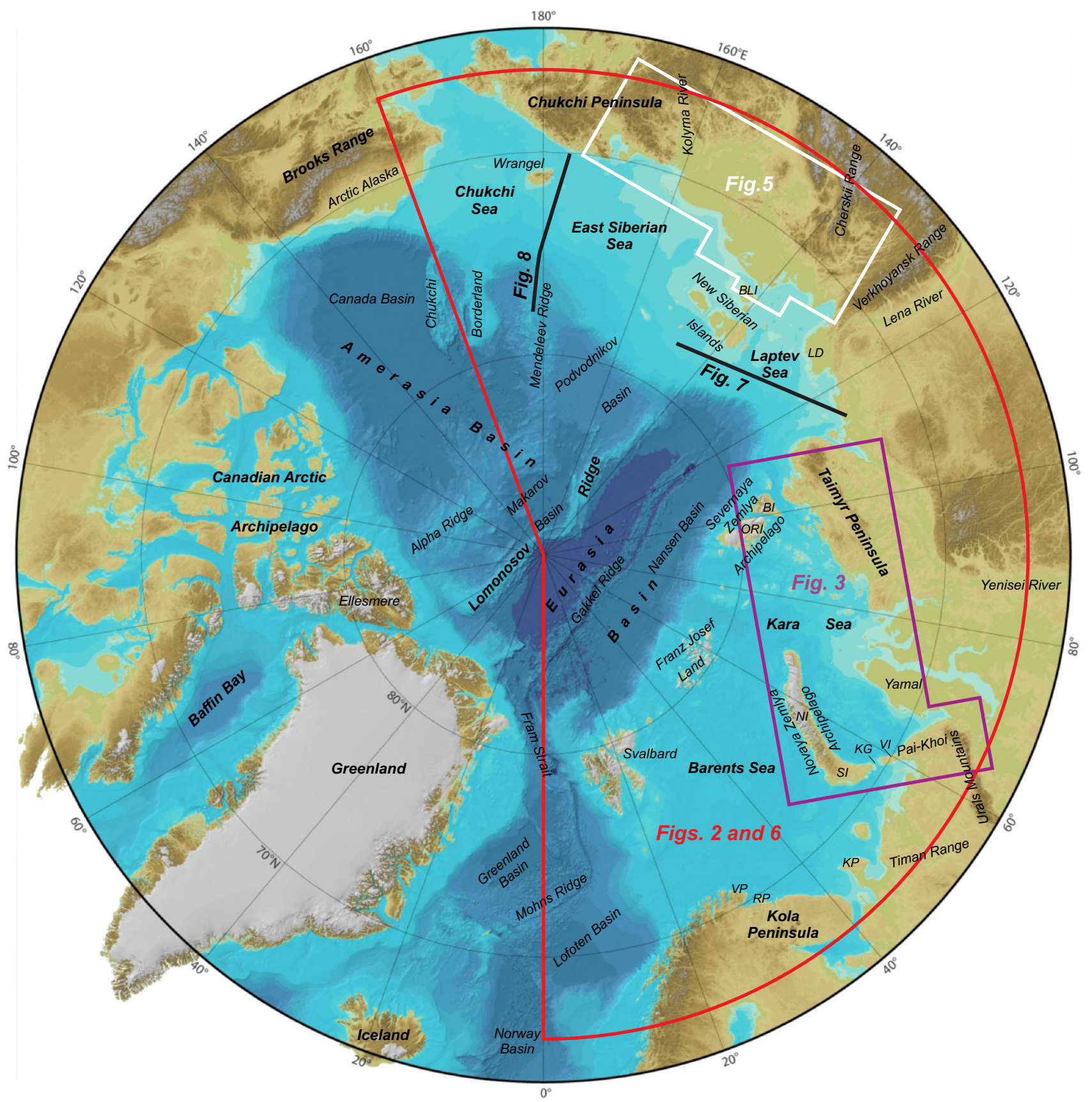

International Bathymetric Chart of the Arctic Ocean (IBCAO, ver.3)

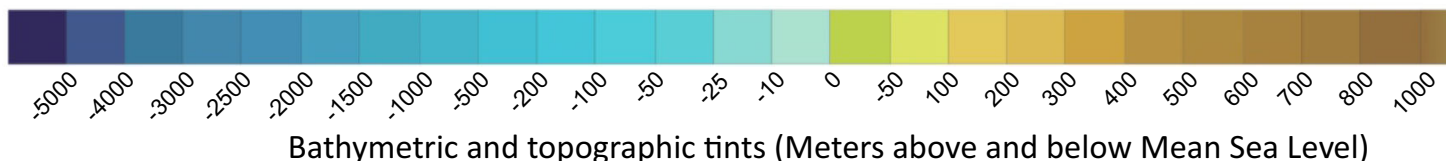

Fig. 1 Physiographic domains and seas of the Arctic region (after Jakobsson et al. 59). Italic capital letters denote: BLI Bol'shoi Lyakhov Island, BI Bolshevik Island, ORI October Revolution Island,

variability in crustal architecture of the orogeny has also been recognized and thus three segments are now distinguished: Southern, Central and Northern [20].
$V I$ Vaigach Island, $K G$ Kara Gate Strait, $L D$ Lena Delta, $V P$ Varanger

Peninsula, $R P$ Rybachii Peninsula (refer to text for more details)

The Central, and Northern segments reach the Arctic. The basal part of the Central Segment comprises a set of parautochthonous and allochthonous sheets dominated by 


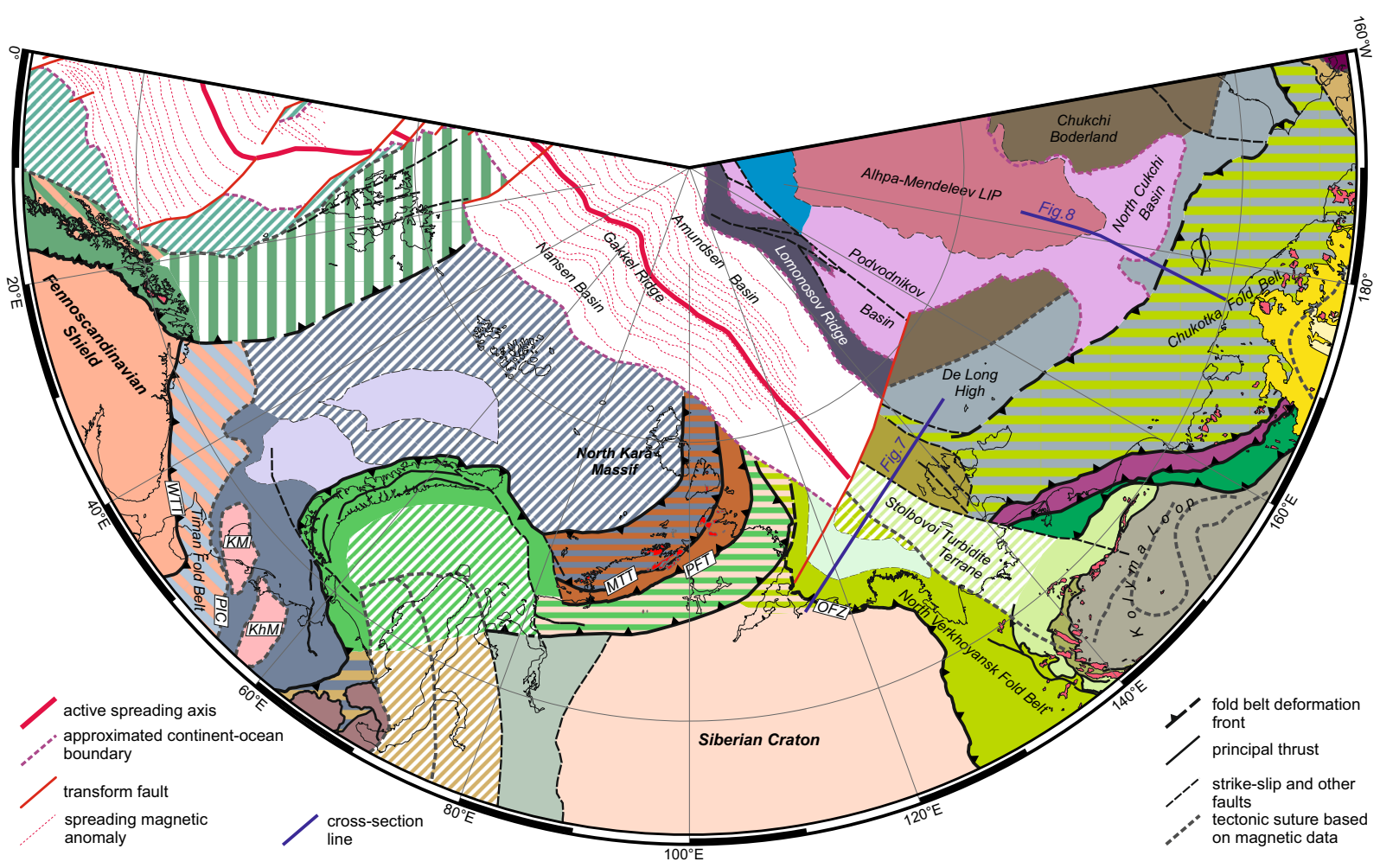

Pre-Neoproterozoic cratons

Baltica Craton

a Siberian Craton; a, deformed foreland

Neoproterozoic-Phanerozoic fols belts

a $\quad$ b c Neoproterozoic Timan Fold Belt: a, Timan domain (deformed margin of Baltica): b, Bol'shezemel'sk domain (accreted terranes and island-arc fragments); $c$, inferred microcontinents; $d$, fold belt inferred offshore

Neoproterozoic Yenisei Fold Belt inferred under sedimentary cover of West Siberian Basin

a $\quad$ b $\quad$ c 107 Early Palaeozoic Caledonian fold belt: a \& b, Scandinavian Caledonides and their inferred

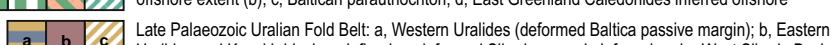

b $\quad$ Uralides and Kazakh block undefined; c c deformed Siberian margin inferred under West Siberia Basin

a $\quad$ b Late Palaeozoic Taimyr Fold Belt: a, Northern Taimyr domain (deformed margin of North Kara Massif);

$\begin{array}{lll}\text { a } & \text { b } & \text { b. Central Taimyr domain (accretionary zone) }\end{array}$

Early Mesozoic Pai-Khoi - Novaya Zemlya - South Taimyr Fold Belt: a, deformed Taimyr Foreland

a Basin underlain by Siberian Craton; $b$, inferred offshore extent beneath South Kara Basin

Late Mesozoic North Verkhoyansk Fold Belt; a, inferred offshore

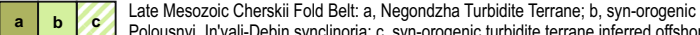

Polousnyi, In'yali-Debin synclinoria; c, syn-orogenic turbidite terrane inferred offshore

Kolyma-Omolon Composite Superterrane

Kotel'nyi Terrane: a fragment of a Palaozoic passive margin involved in Late Mesozoic deformation

Late Jurassic-Early Cretaceous

Oloi-Svyatoi-Nos volcanic arc

Late Jurassic-Early Cretaceous

South Anyui Suture Zone

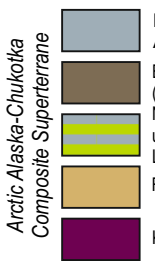

Neoproterozoic BorroviaArctic Alaska Block

Early-Mid Paleozoic undefined

(Caledonian/Ellesmerian)

Neoproterozoic and Paleozoic

undefined affected by Early and

Late Brookian compression

Ruby Terrane

Koyukuk Terrane

Late Cretaceous-Early

Cenozoic Koryak Fold Belt

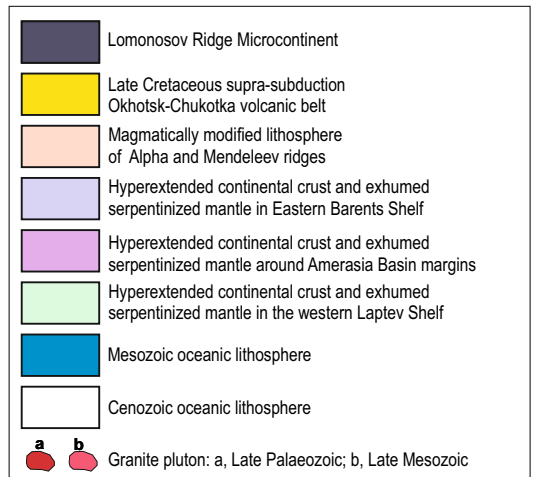


४Fig. 2 Tectonic domains of the Eurasian Arctic consolidated crust (refer to text for more details). Outlined italic capital letters denote PIC Pripecho-Ilych-Chikshinsk Suture, WTT West Timanian Thrust, KhM Khoreiversk Massif, KM Kolguev Massif, OFZ Olenek Fold Zone, MTZ Main Taimyr Thrust, PFT Pyasina-Faddeevskii Thrust. Location of the map is shown in Fig. 1

Late Neoproterozoic metasedimentary rocks of Baltica's continental margin intruded by mafic dyke swarms and overlain by the metasedimentary, amphibolitic, metagranitic and ultramafic rocks of the Seve Nappe Complex. These are tectonically overlain by nappes of Palaeozoic rocks of oceanic affinity capped with a complex stack of nappes comprising allochthons of Precambrian continental crust, Neoproterozoic and Early Palaeozoic platformal sedimentary and turbidite successions, and Ordovician magmatic arc complexes [20]. The Northern Segment is dominated by three tectono-stratigraphic units: parautochthonous and allochthonous Late Neoproterozoic metasedimentary rocks resting on Archean to Palaeoproterozoic basement of the Fennoscandian Shield, possibly allochthonous units of Mesoproterozoic to Early Palaeozoic metasedimentary and igneous rocks of the Kalak Nappe Complex, and allochthonous Ordovician-Silurian metasedimentary and meta-plutonic rocks [20].

The main collisional event, known as the Scandian phase, followed closure of the Iapetus Ocean (encompassing the time between 430 and $380 \mathrm{Ma}$ ) was accompanied by a high- and ultra-high pressure metamorphism [19]. Precambrian Baltic basement exposed in tectonic windows becomes gradually more reworked to the west. Early Devonian high-pressure rocks such as eclogites, locally with coesite and microdiamonds are documented [21] suggesting a W-directed partial subduction of Baltican lithosphere during Scandian collision up to the depths of $\mathrm{c}$. $125 \mathrm{~km}$.

Offshore extent of the CFB into the Barents Sea is a controversial and highly debated issue (see [115, 120] for a summary). The main suture between Laurentia and Baltica was speculated to bifurcate, with one branch located between north Greenland and Svalbard, and another one projecting into the Barents Sea (Gudlaugsson et al. [50, 11, 61]). Gee et al. [43], proposed the suture to be located further east, between the Svalbard and Franz Josef Land archipelagoes, and deformation front approaching Novaya Zemlya and Severnaya Zemlya islands. The recent crustal models provide evidence for the main suture beneath western Spitzbergen [94, 134], with the eastern Caledonian front located west of Franz Josef Land, which is supported by an earlier observation by Pease et al. [117].

\section{Late Palaeozoic Uralian and Taimyr fold belts}

A large region between the Ural Mountains and the Yenisei River (Fig. 1) formed as a result of a Late Palaeozoic collision of the Siberian continent and Kazakhstan-TyanShan Caledonian Composite Superterrane (microcontinent) with the Baltican margin of Laurussia, which is commonly referred to as Uralian orogeny [12, 130, 180, 181]. This tectonism was the culmination associated with the closure of the Neoproterozoic-Palaeozoic Paleoasian Ocean and assemblage of the Pangaea Supercontinent. Presently, rocks affected by the Uralian compression are exposed in the Ural Mountains and in the Taimyr Peninsula, while a major part of this tectonic assemblage is deeply buried under the Mesozoic West Siberian Basin and can only be characterized by deep exploratory wells [54, 55].

\section{Uralian fold belt (UFB)}

The UFB stretches N-S for c. $2500 \mathrm{~km}$ from the Aral Sea to the Kara Sea coast. Its western flank is exposed in the Ural Mountains while the remaining part occurs beneath West Siberian Basin. It is subdivided into five along-strike segments, of which the only northernmost segment, known as the Polar Urals, is located in the Arctic. Comprehensive overviews of Uralian geology were published by Brown et al. [12, 13], Puchkov [130, 133].

The exposed UFB is subdivided into the western and eastern tectonic-stratigraphic zones, separated by the narrow intensely deformed Main Uralian Fault, which includes fragments of ophiolites [130]. The western zone, known also as the Western Uralides, is composed of up to $6 \mathrm{~km}$ of Ordovician-Carboniferous shelf carbonate and siliciclastic rocks of Baltican passive margin thrusted onto the Baltica craton. This proximal complex is overthrusted by a distal succession of calcareous shale and chert of deepwater continental margin. Thrusts also involve Neoproterozoic Timanian basement, known as the Proto-Uralides [139], which is exposed in a series of tectonic windows named as Central Uralian Zone [65, 131, 133]

The Eastern Uralides is mostly composed of late Devonian to $\mathrm{mid} / \mathrm{late}$ Carboniferous metamorphic and igneous rocks of volcanic arc affinity-fragments of the Mid-Palaeozoic Tagil-Magnitogorsk island-arc system developed along the Baltican margin in Devonian time as a result of westerly directed subduction of the Palaeo-Uralian Ocean [4, 140]. Post-tectonic Permian (290-250 Ma) granites indicate significant crustal thickening during the final collision stage [4, 130, 140].

According to Puchkov [130-132], the UFB tectonic history can be summarized as follows: 
1. Initial rifting in Cambrian-Middle Ordovician followed by spreading opening of the Palaeo-Uralian Ocean and formation of the Baltican passive continental margin.

2. Formation of the magmatic Tagil Island Arc at the end of Ordovician.

3. Formation of the Magnitogorsk and Valerianovsk magmatic island arcs in Emsian (Middle Devonian) and Serpukhovian (Early Carboniferous) times as a results of reconfiguration of the Tagil subduction zone.

4. Collision of the Magnitogorsk island arc with the Baltican margin in the latest Devonian-early Carboniferous.

5. Collision of the Laurussian Continent with the Kazakh Microcontinent in Bashkirian (Middle Carboniferous) time and formation of the bi-vergent orogen.

6. Voluminous granitoid plutonism during Permian time resulted in the formation of the so-called Granite axis of the Urals.

Uralian orogenesis was completed by end-Permian time, and the territory of the newly formed continental crust was involved in Permo-Triassic uplift associated with the Siberian Superplume event.

\section{Taimyr fold belt (TmFB)}

The TmFB occupies the entire Taimyr Peninsula and extends onto the adjacent Kara and Laptev shelves and the eastern part of the Severnaya Zemlya Archipelago where it crops out on Bolshevik Island and in eastern part of October Revolution Island (Figs. 1, 2). The fold belt consists of three major tectono-stratigraphic domains: Northern Taimyr-Severnaya Zemlya, Central Taimyr, and Southern Taimyr separated by the Main Taimyr and Pyasina-Faddeevskii thrusts, respectively [53, 164, 166]. The Southern Taimyr domain represents a younger Mesozoic fold belt and thus is considered separately.

The Northern domain is dominated by NeoproterozoicCambrian siliciclastic turbidites, which are interpreted as an indicator of a passive continental margin of the so-called North Kara Microcontinent. Basement underlying these turbidites is not exposed but can be inferred based on detrital zircon ages from the turbidites. The latter bear a profound Timanian signature and thus suggest proximity of this crustal block to the Baltica Continent [29, 90, 91, 116]. The rocks are intensively deformed and regionally metamorphosed in lower greenschist (Bol'shevik Island) to moderate amphibolite (Northern Taimyr) facies and intruded by Late Palaeozoic syncollisional granite plutons varying in age between c. 343 and c. $290 \mathrm{Ma}[89,91,163-$ 165]; 260-245 Ma post-collisional granites [91, 167] are apparently associated with the Siberian (Tunguska) Plume.
The deformation and metamorphism history of the Northern domain is not well understood. Although, the main deformation and metamorphism are associated with Late Palaeozoic orogeny [115, 116, 166], Proskurnin [129] suggest an earlier, late Timanian (Mid-Late Cambrian) compressional event to have affected the Bolshevik Island turbidites, which were then involved into the Late Palaeozoic deformation.

The Central Taimyr Domain reveals a more complex structure. It is composed of Mesoproterozoic metamorphic rocks (Mamont-Shrenk and Faddey granite-gneiss terranes intruded by 900-850 Ma granites), Neoproterozoic volcanic rocks with island arc affinity, ophiolites and associated 740-720 Ma plagiogranite. These rocks underwent compressional deformation in the late Neoproterozoic (c. $600 \mathrm{Ma}$ ) as a result of island arc accretion to the Siberian margin, and are unconformably overlain by latest Neoproterozoic and Palaeozoic sedimentary rocks associated with a passive margin of Siberia continent [7, 118, 161, 164-166]. The entire section of the domain is compressionally deformed and intruded by Carboniferous to Permian granites, during the main phase of the Late Palaeozoic orogenesis.

\section{Early Mesozoic Pai-Khoi-Novaya Zemlya-South Taimyr fold belt (PNZST)}

The PNZST formed at a very complex junction of the Baltican and Siberian cratons with the northern part of the Late Palaeozoic Uralides. It stretches for c. $3000 \mathrm{~km}$ through the Yugorsk Peninsula, Vaigach Island, the Novaya Zemlya Archipelago, the central part of the Kara Sea and southern Taimyr Peninsula to the Laptev Sea coast (Fig. 2). The outstanding feature of the fold belt is its curvature. There are four large along-strike segments different in structure and stratigraphy: Pai-Khoi-Vaigach, Novaya Zemlya, Central Kara and South Taimyr (Fig. 3).

The Pai-Khoi-Vaigach Segment stretches for c. $400 \mathrm{~km}$ in an SE-NW direction, orthogonal to the strike of the Uralian Fold Belt, from the Kara Gate Strait to the Kara River midstream area where it is overthrusted by rocks of the Western Uralides. The structural style of the segment is characterized by a thin-skinned NE to SW-directed thrust structure combined with a significant sinistral component [158].

Southwestern boundary of the segment with the Korotaikha Foreland Basin coincides with the South Pai-Khoi Thrust. The NE flank of the basin is involved into thrusting and is known as the Pripaikhoi Zone, often considered a part of the fold belt (Fig. 3). The orogen is composed of two major thrust sheets: the South Pai-Khoi Parautochthon and the Pai-Khoi (Kara by Timonin et al. [158] Allochthon separated by the Main Pai-Khoi Thrust [158]. The former 


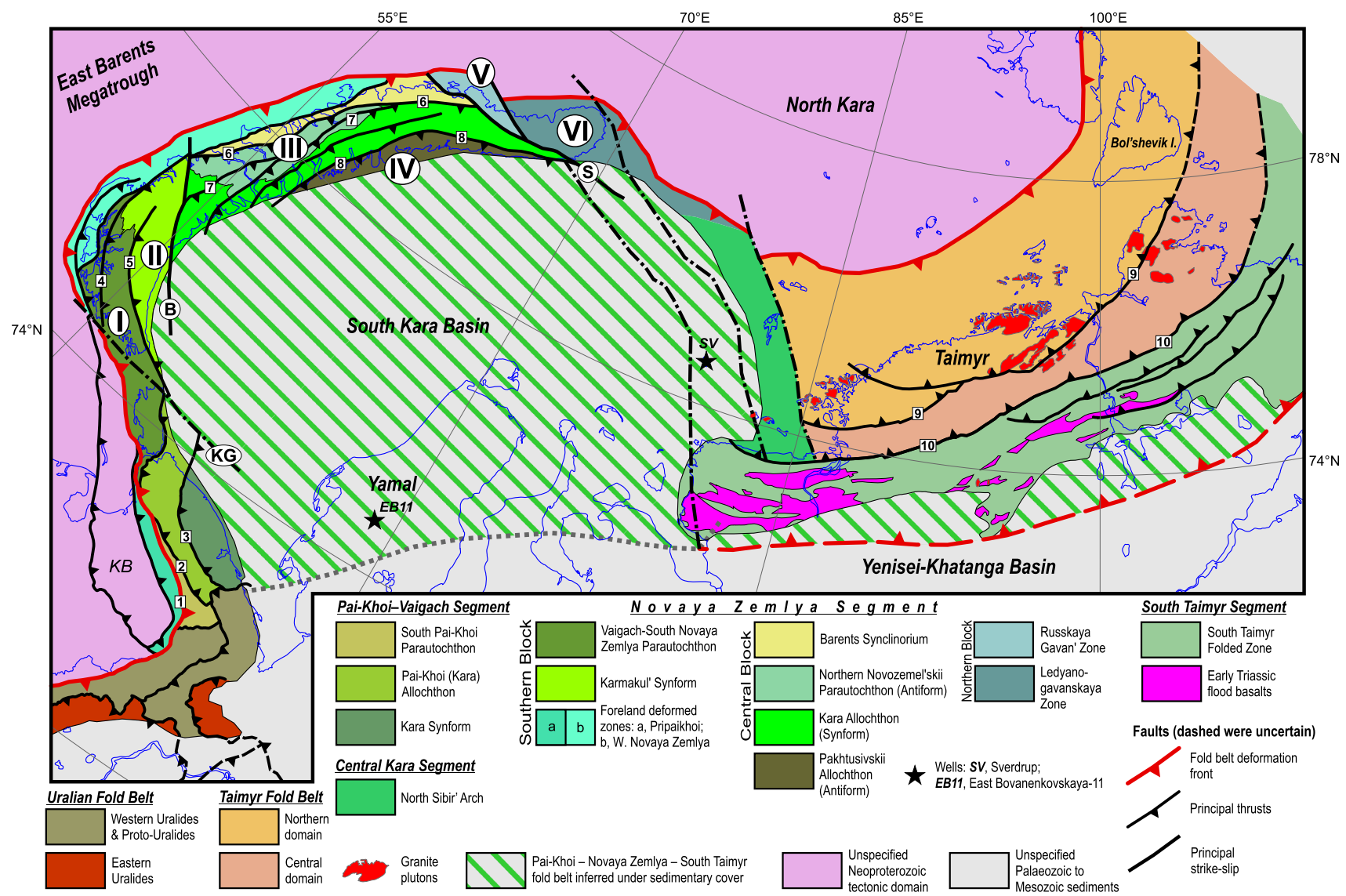

Fig. 3 Tectonic map of the Greater Kara region showing structural subdivisions of the Pai-Khoi-Novaya Zemlya-South Taimyr Fold Belt and its inferred extent under sedimentary cover. Bold encircled letters denote principal transcurrent faults: $B$ Baidaratskii, $S$ Sporonavolokskii. Encircled Roman numerals show location of the stratigraphic columns given in Fig. 4. Squared Latin numerals denote

apparently extends NW to include Vaigach Island, and therefore can be called Pai-Khoi-Vaigach Parautochthon. It is composed of Ordovician to Carboniferous shelfal facies considered proximal to Baltica, mostly carbonate rocks, with total apparent thickness of 6-7 km. The Kara Allochthon is dominated by a succession of Upper Cambrian to Lower Permian shale and chert deposited in a distal passive margin setting. The total exposed thickness varies between 2.7 and $6.1 \mathrm{~km}$. The Ordovician section includes some basalt flows and beds of volcaniclastic rocks. The entire section is intruded by numerous Late Devonian mafic sills and dykes corresponding to a major extensional episode.

The northeastern flank of the Kara Allochthon is tectonically overlapped by the Kara Synform (depression) composed of complexly deformed Early Permian siliciclastic rocks. The lower $1.0-1.6 \mathrm{~km}$ of the section is composed of deep-water shaly and pelitic turbidites derived from the east [87], and an upper $2.0-2.2 \mathrm{~km}$ principal thrusts mentioned in text: 1 South Pai-Khoi, 2 Main PaiKhoi, 3 North Pai-Khoi, 4 Rogachevskii, 5 Kolodkinskii, 6 Main Novosemel'skyii, 7 Tsentral'no-Novozemel'skii, 8 Pakhtusovskii, 9 Main Taimyrskii, 10 Pyasina-Faddeevskii. $K B$ Karataikha Basin. Location of the map is shown in Fig. 1. Based on Lopatin [87], Timonin et al. [158]

interval consisting of more coarse-grained clastic rocks with coal beds deposited in an interchanging shallow water and continental environment.

Sedimentary rocks of the Pai-Khoi Parautochthon and Kara Allochthon facially resemble the Yeletskaya and Lemvinskaya zones of the Western Uralides and were apparently deposited along the same Baltica continental margin. However, the timing of deformation is different: Late Carboniferous in the Urals, and Late Triassic in PaiKhoi. Other outstanding differences between these fold belts do not allow them to be united into a single orogen. These include: (1) orthogonal strike of the Pai-Khoi thrusts relative to thrusts of the Western Urals; (2) the abundance of syncollisional Permian granites in the Urals and their absence in Pai-Khoi; (3) the absence of ophiolites and magmatic arc complexes in Pai-Khoi, which are abundant in the Eastern Uralides.

The Novaya Zemlya Segment forms the 950-km-long central part of the fold belt with a pronounced curvature 
towards the Barents Sea (Fig. 3). As shown by Bondarev [9], Lopatin et al. [86], Pogrebitskiy [123] and Korago et al. [70, 71], it is mostly composed of Palaeozoic to Early Triassic successions deposited across a Baltican passive continental margin with shelf facies developed along the western coast of Northern Novaya Zemlya Island and hemipelagic to pelagic facies-along the eastern coast. The total thickness of the exposed section exceeds $13 \mathrm{~km}$. The entire sedimentary section was severely deformed at the end of the Triassic-earliest Jurassic [86, 123, 142].

Locally exposed basement is represented by Meso- and Neoproterozoic metasiliciclastic turbidite succession and a unit of metacarbonate-metasiliciclastic rocks intruded by Neoproterozoic metagabbro-dolerite dikes and granitoid plutons and deformed under $\mathrm{N}-\mathrm{S}$ trending compression and metamorphosed in greenschist to epidote-amphibolitemigmatite facies, and [70]. Corfu et al. [17] documented presence of 716-704 Ma old mafic dikes exposed along the western coast of Northern Island, which were previously interpreted as associated with the Late Devonian rifting. Geochemistry of the dikes suggests their emplacement in a supra-subduction setting. According to Bogolepova and Gee [8] and Pease and Scott [116], the age of the compressional deformation here is inferred to be Timanian and is younger than in the Timan-Pechora Timanides, possibly as young as mid to late Cambrian.

Based on the distribution of facies and thicknesses of sedimentary successions, the segment is subdivided into three along-strike blocks: Southern, Central and Northern, divided by two large transcurrent faults oriented oblique to the westerly tectonic transport direction: the Baidaratskii in the south, and Sporonavolokskii in the north (Fig. 3).

The Southern block occupies the Southern Island of the Novaya Zemlya Archipelago. Its structure is dominated by a large antiform of the Vaigach-South Novaya Zemlya Parautochthon (Southern Novozemel'sky Anticlinorium) in the southwest, and by the Karmakul' Synform (synclinorium) in the north bounded by the Rogachevskii and Kolodkinskii thrusts, respectively (Fig. 3). A distinct base Frasnian angular unconformity splits the section into two parts (Fig. 4, column I). The lower part mostly occurs within the antiform, and is dominated by Cambro-Ordovician to Middle Devonian shallow-water carbonate rocks. The upper part crops out in the Karmakul' Synform and is mostly composed of Upper Devonian to Lower Permian carbonate and siliciclastic rocks. There is a clear north-directed facial transition to a basinal setting. The Lower Frasnian interval is characterized by a significant volume of the basalts and related volcaniclastic rocks, which are considered to be related to a prominent crustal extension event $[86,123]$. There is a significant amount of the Early Frasnian sills and dikes occurring mostly within Lower and Middle Devonian section. A c. 2- to 3-km-thick
Upper Permian siliciclastic succession caps the section. It is composed of deep-water prodelta facies that transition upwards into more shallow-water deltaic facies sourced from the Uralian orogen [116].

The Central block (northern part of Southern Island and central part of Northern Island) is occupied, in its axial zone, by the Northern Novozemel'skii Parautochthon (Anticlinorium). It is flanked by the West Novozemel'skaya Zone and the Kara Allochthon (Synclinorium) in the west and east, respectively (Fig. 3). These tectonic units are bounded by prominent thrusts: the Main Novosemel'skyii and Tsentral'no-Novozemel'skii, respectively. Another large fault, the Pakhtusovskii Thrust, is mapped along the eastern flank of the Kara Synclinorium, which divides it from the easternmost Pakhtusov Antiform. The allochthons bounded by these thrusts differ significantly in facial character.

The West Novozemel'skaya Zone of frontal deformations (the Barents Facial Zone) is composed of an Upper Devonian to Carboniferous shallow-water carbonate platform overlain by a basinal Lower Permian black shale unit and a succession of Upper Permian prodelta turbidites capped by Upper Permian to lowermost Triassic shallow marine and fluvial siliciclastic rocks (Fig. 4, column III). The Lower Frasnian interval is abundant with the basalt flows and associated volcaniclastic rocks, marking the same extension event as the analogue unit in the Southern Block. However, according to Corfu et al. [17], some mafic dikes are 716-704 Ma old. The Northern Novozemel'skii Anticlinorium (the Mityushikhin Facial Zone) reveals a c. 4- to 6-km-thick Cambrian to Lower Devonian section of deep-water and prodelta turbidites that transition upwards into shallow-water siliciclastic and carbonate rocks (Fig. 4, column III).

The thrust sheets exposed in Pakhtusovskii Anticlinorium and Kara Synclinorium are composed of the Devonian to Early Permian hemipelagic and pelagic rocks (Fig. 4, column IV): fragments of pelagic shale and chert units with radiolaria and conodont fauna, distal mudstone dominated turbidites, lenses of carbonate breccia. Associated with this section are fragments of Upper Devonian pillow basalts and thin bodies of serpentinized peridotites, which were interpreted as products of Devonian rift event (see above), but could be fragments of a dismembered ophiolite complex. Middle Carboniferous to Middle-Upper Permian rocks are represented by deep-water shale and distal turbidites and Upper Permian prodelta turbidites transitioning upward into a succession of shallow-marine siliciclastic rocks.

The Northern block (northern part of Northern Novaya Zemlya Island) consists of two contrasting tectono-stratigraphic zones (Fig. 3). The westerly Russkaya Gavan' Zone comprises a c. 5.5- to 7-km-thick Silurian to Upper 


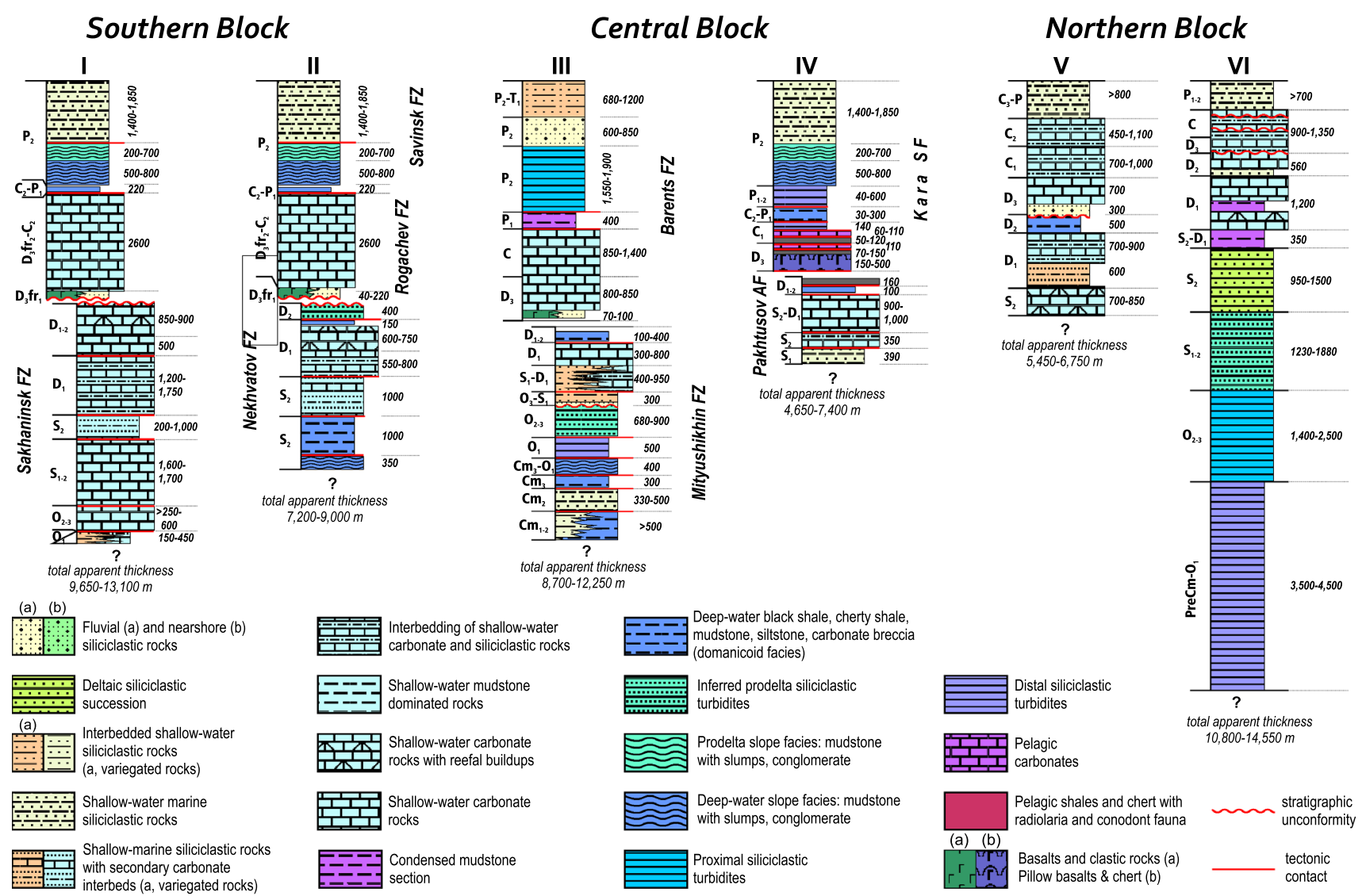

Fig. 4 Generalized stratigraphy of the Novaya Zemlya Archipelago (based on [123]. Location is shown in Fig. 3

Permian section that is similar to the Barents Synclinorium and North-Novosemel'skii Anticlinorium sections (Fig. 4, column V). The northernmost Ledyanogavanskaya Zone is dominated by a thick succession of siliciclastic Neoproterozoic to Upper Ordovician turbidites that transition into a thick unit of Silurian prodelta turbidites (Fig. 4, column VI), which are unknown in the other parts of the fold belt. No any significant unconformities have been documented in this section so far. The upper part of the section closely resembles the westerly Devonian to Permian sections and is represented by Devonian to Carboniferous shallow marine carbonate and clastic rocks overlain by shallowwater Permian clastic rocks. The total thickness of the exposed section in the Northern Block exceeds $14 \mathrm{~km}$.

The deformed sedimentary successions of the Novaya Zemlya Segment are intruded by a few small bodies of granitic rocks with Late Triassic to Early Jurassic isotopic ages [123].

The age of compressional deformation was, for a long time, one of the most disputed issues of Arctic geology (see [115]). The youngest strata involved in the deformation are of Early Triassic age, which presumes deformation must be younger. Modern unpublished MCS data acquired by TGS
Seismic Company in the vicinity of the western coast of Novaya Zemlya show a sharp angular unconformity at about the Triassic/Jurassic boundary, which probably corresponds to the main deformation phase.

The Central Kara Segment occurs completely under sedimentary cover of the Kara Sea. It coincides with a prominent gravity high called in Russian literature the North Siberian Arch (or Step). This structure has, for a long time, been seen as a link between the Novaya Zemlya and Taimyr orogens [146]. A well drilled in the late 1980s on Sverdrup Island situated over the crest of this feature (Fig. 3) penetrated crystalline schists beneath $1.6 \mathrm{~km}$ of Cretaceous-Upper Jurassic undeformed siliciclastic sediments [146]. The schists are inferred to be of Proterozoic age and therefore can be interpreted as Timanian basement involved in the Early Mesozoic deformation. So far, no isotopic age has been yielded from these rocks.

The South Taimyr Segment (STS) stretches for over $1000 \mathrm{~km}$ between coasts of the Kara and Laptev seas. In the north, it is bounded by the Pyasina-Faddeevskii Thrust, and in the south is covered by post-orogenic Jurassic and Cretaceous sedimentary fill of the Yenisei-Khatanga Basin (Fig. 3). 
The STS is interpreted to represent a Siberian passive margin overlain by a foreland basin developed in conjugation with the Late Palaeozoic Taimyr Fold Belt, both folded and thrusted to the south in the early Mesozoic. It is dominated by c. 7- to 8-km-thick succession of unmetamorphosed Ordovician to Carboniferous carbonate and siliciclastic rocks overlain by a thick shallow-water and nearshore siliciclastic Permian to Early Triassic rocks with significant amounts of Tunguska-like basalts and accompanying sills and dikes associated with the c. $250 \mathrm{Ma}$ Siberian Superplume event. According to Zhang et al. [179], U-Pb detrital zircon ages and heavy mineral analyses indicate a dominant Uralian provenance with some additional Timanian and Caledonian material presumably derived from interleaved thrust sheets of Baltica affinity. However, the same age rocks are known in Northern Taimyr domain and so more local provenance cannot be excluded. All strata, including the basalt flows and sills, are deformed into south-verging folds and thrusts decreasing in intensity towards the Siberian Craton.

The age of STS deformation is bracketed by Early Triassic mafic and granitic rocks that intrude Permian and Early Triassic sedimentary rocks, and by the Early Jurassic basal strata of the Yenisei-Khatanga Basin that onlap the STS folds [53, 176].

Offshore extent of the PNZST fold belt beneath southern Kara Sea represents a challenging problem. The proposed model (Fig. 6) allows for its greater extent below the entire South Kara Basin, based on the idea by Ustritsky [162] about trapped lithosphere relict of Paleozoic Uralian Ocean. The latter was further developed by Sullivan et al. [156], Scott et al. [142], and Drachev et al. [26], who implied subduction rollback was a driving mechanism of the PNZST formation. The southernmost occurrence of deformed Triassic rocks was documented by the East Bovanenkovskaya-11 well on Yamal Peninsula ([149]; see Fig. 3 for location), and in the lower Yenisei River. Therefore, the PNZST extent could potentially be traced for over 800-900 km in SE direction below the South Kara and northern part of the West Siberian Basin.

\section{Late Mesozoic fold belts and composite superterranes}

The huge region between the Siberian and North American cratons is occupied by a series of fold belts and large composite terranes. These terranes were accreted during Jurassic and early Cretaceous time as the result of closing two ocean basins, the South Anyui-Angaucham, and the Oimyakon oceans. This oceanic closure and the following orogenesis created a continental bridge between the Eurasian and North American continents around 130-125 Ma. The North Verkhoyansk, Cherskii, Chukotka, and Brooks
Range fold belts, as well as Arctic Alaska-Chukotka Microcontinent (AACM) and Kolyma-Omolon composite superterrane (KOCS) are the first-order elements of this extremely heterogeneous tectonic ensemble (Fig. 2). The former two together with the KOCS are often named as Verkhoyansk-Kolyma Fold Belt, or orogen [108]. Detailed characteristic of the geology of this region is provided by Zonenshain et al. [181], Parfenov [109], Nokleberg et al. [106, 107], Parfenov and Kuz'min [111], and Oxman [108], and more recently by Sokolov [151] and Toro et al. [160].

\section{Verkhoyansk-Kolyma orogen}

The North Verkhoyansk Fold Belt (Figs. 2, 5) and its western branch, the Olenek Fold Zone, represent the deformed Palaeozoic to Mesozoic passive margin of the eastern Siberian Palaeocontinent [109, 181]. The fold belt is dominated by c. $15 \mathrm{~km}$ of Upper Paleozoic to Lower Cretaceous (Hauterivian) siliciclastic rocks resting on lower Palaeozoic shallow-marine carbonate and clasticcarbonate formations, which in turn are underlain by Neoproterozoic clastic successions. In Late Devonian time, the passive margin underwent significant extension and fragmentation culminating with the formation of Oymyakon Ocean; in Late Jurassic and Early Cretaceous (Neocomian) time it was affected by the west-directed thrusting and folding during collision with the KOCS and the AACM [106, 108, 113, 138].

Since the first MCS data were collected in mid-1980s, the offshore extent of the Verkhoyansk Fold Belt and nature of the Olenek Fold Zone remained among the most disputed questions of Laptev Sea geology. The former, as a narrow strip of deformed Upper Palaeozoic and Mesozoic rocks, extends along the Laptev Sea Coast and was considered either as a narrow inverted Precambrian rift within the Siberian Craton, or as a frontal zone of the Verkhoyansk Fold Belt extending onto the adjacent shelf (see [23] for more details). The recent MCS data published by Zavarzina et al. [178] seem to confirm the latter.

The Cherskii Fold Belt (Fig. 2) formed in the latest Jurassic/earliest Cretaceous during KOCS collision with the Verkhoyansk margin of Siberia [106, 109]. It consists of a series of terranes dominated by deep-water siliciclastic turbidites accumulated in the Oimyakon palaeo-oceanic basin (Kular-Nera and Nagondza terranes), fragments of the Omulevka Microcontinent, and stacked allochthons of ophiolite and metamorphosed rocks [108, 112, 160] (Fig. 5).

The Kular-Nera Slate Terrane and stretches NW-SE from Laptev Sea coast, along western fringes of the Cherskii Range towards the Sea of Okhotsk for the distance of over $1300 \mathrm{~km}$. It comprises Upper Permian, Triassic and 


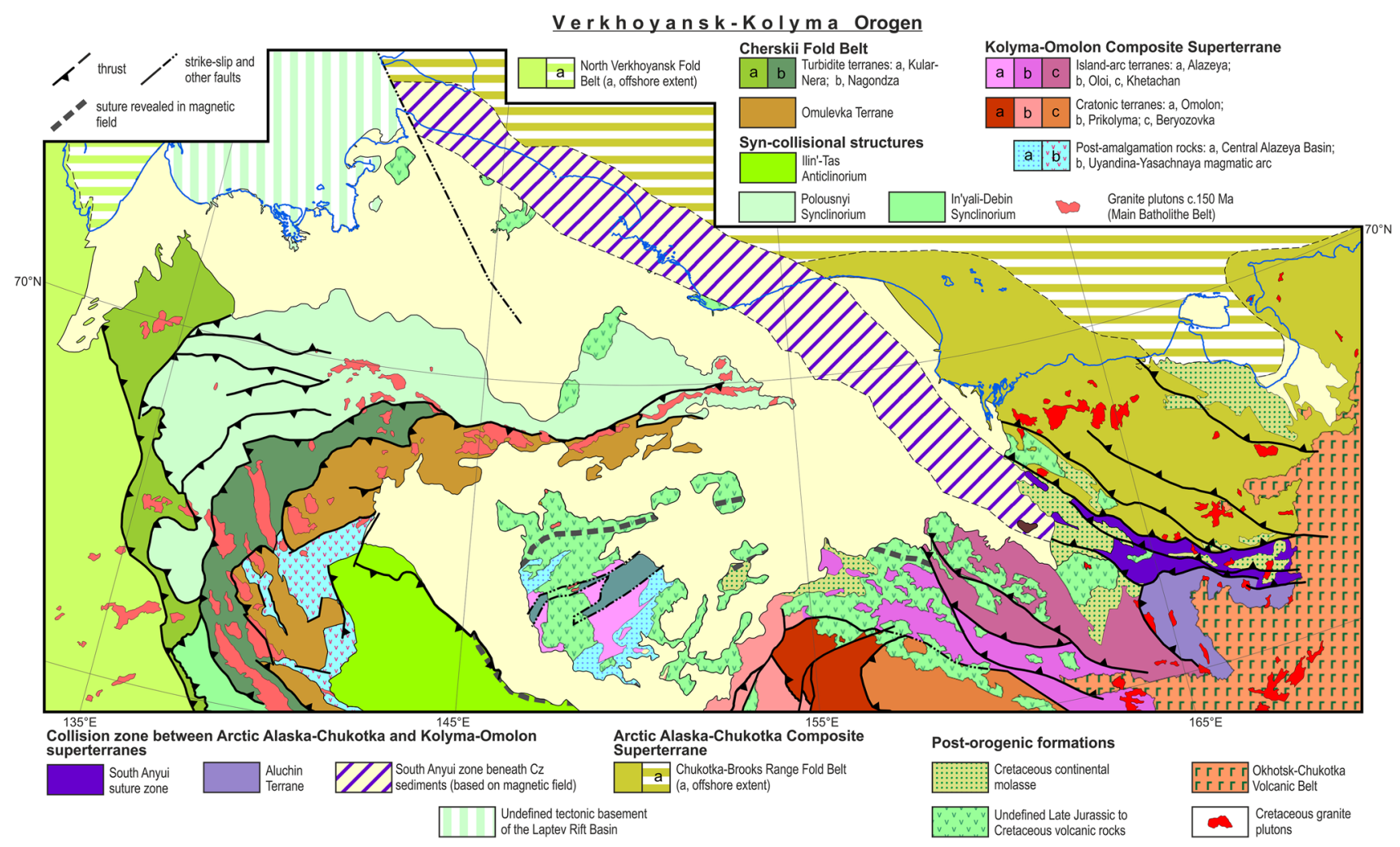

Fig. 5 Principal tectonic elements of Northeast Asia (based on Parfenov [109], Nokleberg et al. [106], Parfenov and Kuz'min [111], Oxman [108]. Location of the map is shown in Fig. 1

Lower Jurassic pelagic and hemipelagic shale and distal turbidites and conturites. The Adycha-Taryn Fault separating it from the North Verkhoyansk FB marks the easternmost limit of the Siberian palaeocontinent [109].

The Nagondza Turbidite Terrane (Tuostakh Block) is composed of polydeformed Upper Palaeozoic, Triassic and Lower Jurassic distal clastic turbidites. Tectonically fragmented Permo-Carboniferous rocks with layers of pillow basalts occur along its eastern flank and are interpreted to indicate rifting.

The Omulevka Microcontinent (terrane) is composed of Palaeozoic (Lower Ordovician to Lower Carboniferous) carbonate and siliciclastic-carbonate rocks and is inferred to represent a large fragment of the Siberian continental margin rifted away during Late Devonian-Early Carboniferous time [181]. However, Parfenov [109] considers it to be a part of the KOCS.

The Kolyma-Omolon Composite Superterrane (KOCS) was assembled in early Mid-Jurassic time due to a collision of a Late Palaeozoic-Early Mesozoic island arc system (Alazeya, Oloi and Khetachan terranes) with the Omolon Microcontinent (Omolon, Prikolyma and Beryozovka terranes). The newly formed KOCS collided then with the Omulevka Microcontinent in Bajocian time [109, 111].
The Omolon Terrane (massif) forms the KOCS's core. Its basement is composed of Archean and Palaeoproterozoic crystalline rocks, which are overlain by non-metamorphosed to very low grade metamorphosed Mesoproterozoic to Cambro-Ordovician rock units with rift-related basalts and rhyolites. These rocks are overlain, with a sharp angular unconformity, by Middle-Upper Devonian andesites, dacites and rhyolites and associated volcaniclastic and siliciclastic rocks forming a supra-subduction Kedon magmatic belt, which is capped by a thin unit of Upper Devonian shallow-water siliciclastic and carbonate rocks. A thick succession of Upper Carboniferous, Upper Permian, Upper Triassic, Lower and Middle Jurassic shallow-marine siliciclastic rocks unconformably overlie the Precambrian and Devonian rocks.

The Prikolyma and Beryozovka terranes are inferred to represent passive margin fragments once adjacent to the Omolon Terrane [109]. Their sections are composed of c. 10-km-thick passive margin sedimentary wedges resting on Precambrian basement. Neoproterozoic volcanic rocks documented in the Prikolyma Terrane are considered to be associated with the crustal extension. Another crust extension episode is marked by the Middle-Late Devonian basalt volcanism [14]. Supra-subduction volcanic and 
associated volcaniclastic rocks are known in the overlying Permian-Triassic shallow-marine siliciclastic succession, which may suggest proximity of this terrane to an active Late Palaeozoic island arc.

The Alazeya Island Arc terrane is poorly exposed and thus is much less understood. It probably consists of two subterranes: Alazeya and Kenkel'da. The former is dominated by a up to 6-km-thick succession of gently deformed Devonian-Carboniferous, Permian, Late Triassic and Early Jurassic shallow-water arc-related volcanogenic-sedimentary rocks with layers of basalt, andesite and dacite. The latter includes metamorphic rocks including metabasalts, glaucophane and glaucophane-lawsonite schists, siliciclastic and volcaniclastic rocks, and oceanic tholeiitic basalts. It is inferred to represent a fragment of the Alazeya island arc accretionary wedge. The weakly deformed Middle and Upper Jurassic shallow-water rocks unconformably overlie the older rocks of the terrane.

The Khetachan Terrane is composed of deformed Upper Triassic and Early Jurassic volcanic and volcaniclastic rocks and is inferred to represent a fragment of the Alazeya Island Arc. It is overlain, with angular unconformity, by post-amalgamation Late Jurassic volcanic and volcaniclastic successions of the Oloi magmatic arc [111].

The Oloi Island Arc Terrane is composed of MiddleUpper Devonian rhyolite lava flows and tuff, basalts and intercalating limestone and siliciclastic beds, Lower to Middle Carboniferous siliciclastic rocks, Lower Permian siltstone and sandstone, and Upper Permian unit of interbedded volcaniclastic and siliciclastic rocks.

Post-amalgamation rocks overlie, with sharp basal angular unconformity, the KOCS terranes. They include Middle Jurassic (Bathonian-Callovian) olistostrome, volcanic and volcaniclastic rocks of the Upper Jurassic (Oxfordian-Tithonian) Uyandina-Yasachnaya and the Upper Jurassic to Neocomian Oloi-Svyatoi-Nos magmatic arcs, Middle-Upper Jurassic and Neocomian siliciclastic and volcanogenic rocks of the Ilin'-Tas Anticlinorium, and Middle-Upper Jurassic shallow marine siliciclastic sediments of the Central Alazeya Basin. The magmatic arc rock complexes manifest subduction of the Oimyakon and South Anyui oceanic lithosphere under W-SW (Uyandina-Yasachnaya Arc) and NW (Oloi-Svyatoi-Nos Arc) KOCS's margins. All post-amalgamation formations were affected by moderate to weak compression at the end of the Neocomian, except for the rocks of the Ilin'-Tas Anticlinorium that were deformed into tight isoclinal folds.

The Syn-collisional Polousnyi, In'yali-Debin synclinoria, and Ilin'-Tas Anticlinorium are mostly composed of Middle to Upper Jurassic siliciclstic and volcaniclastic turbidites accumulated between the colliding KOCS and the Siberian margin. Numerous signs of syn-sedimentary deformation, presence of sedimentary mélange and tectonic olistostrome, layers of andesite and basalt rocks and volcaniclastic material indicate deposition of the turbidites in a tectonically active environment close to volcanic centers. Based on these facts, the Polousnyi, In'yali-Debin synclinoria are inferred to represent large fragments of accretionary prisms [111].

\section{South Anyui Suture zone (SASZ)}

The SASZ is a narrow intensely deformed tectonic zone separating the compressionally deformed New SiberianChukchi margin of the AACM from the VerkhoyanskKolyma orogen (Fig. 5). Many data on SASZ geology were published by Parfenov and Natal'in [110], Sokolov et al. [152-154], Amato et al. [1]. The suture is exposed onshore in Western Chukotka where it is composed of a complexly deformed package of tectonic nappes thrusted southward onto the adjacent margin of the KOCST as revealed by seismic refraction data $[1,44]$. The individual nappes consist of Carboniferous volcanic-cherty-carbonate rocks, Upper Triassic-Valanginian volcanic and volcaniclasticsiliciclastic rocks, Upper Jurassic volcanic and siliciclastic rocks of an island-arc affinity, Upper Triassic and Upper Jurassic-Lower Cretaceous turbidites, Upper JurassicLower Cretaceous olistostrome complex; and fragments of Middle-Upper Jurassic and Late Palaeozoic (fragment of inferred Late Paleozoic ensimatic island arc-see [38, 154] ophiolites. The rocks are intruded by syn- and post-collisional granodiorites and granites with isotopic ages of 116-105 Ma [1, 97, 152, 153]. Magnetic data allow to extend the SASZ offshore from the Kolyma River mouth to Bol'shoi Lyakhov Island, where dismembered ophiolites and island-arc volcanic complexes are again exposed [24, 78]. The further offshore continuation of the suture into Laptev Sea is obscured by younger extensional faults of the Laptev Sea Rift System and thus is uncertain (see discussion in [78]). Zonenshain et al. [181] proposed that SASZ can be projected into Southern Taimyr across the Laptev Shelf, but this idea is not supported by neither magnetic nor geological data.

The SASZ formed in Late Jurassic-Early Cretaceous (prior to Aptian) time as the result of the closure of the South Anyui-Angaucham Ocean and collision between the AACM and an active continental margin of the North Asian continent represented by the Oloi-Svyatoi Nos magmatic arc [110, 138, 181]; Sokolov et al. [152, 153]. The deformation timing is bracketed by the youngest compressionally deformed Hauterivian-Barremian sedimentary rocks, and the oldest $116.9 \pm 2.5 \mathrm{Ma}$ [97] granite pluton cross-cutting the deformed rocks. The final collision was accommodated by movements along large WNW to ESE dextral strike-slip faults [153]. 


\section{Arctic Alaska-Chukotka Microcontinent (AACM)}

The AACM is a large tectonic domain (or superterrane) occupying most of the East Siberian Sea and the entire Chukchi Sea, Chukotka Peninsula, Arctic Alaska and Brooks Range (Fig. 2). The Chukchi Borderland is inferred to be a part of the AACM that was partially detached from it during opening of the Amerasia Basin [49]. The AACM is inferred to have been attached to the Canadian margin of present-day North America in Late Palaeozoic and early Mesozoic, and to have rifted away in Late Jurassic and continued drifting in Early Cretaceous until it collided with the accreted Siberian/ KOCS margin in latest Neocomian (c. 130-120 Ma) time. This collision caused the closure of the South Anyui-Angaucham Ocean and formation of the South Anyui Suture and the Chukotka and Brooks Range fold belts [138, 181]. The full extent of the AACM is currently debated (see discussion in [115]).

The AACM can be subdivided into southern and northern domains, which are separated by the Early Brookian frontal thrusts of the Brooks Range Fold Belt, Lisburne Peninsula-Wrangel-Herald compressional front, and a zone of north-verging compressional deformation mapped in sparse seismic data north of Wrangel Island and in the East Siberian Sea [23, 47, 48, 170]. Therefore, southern part of the AACM underwent compressional deformation in Neocomian time, while its northern part comprising fragments of the Neoproterozoic and Caledonian/Ellesmerian fold belts remained intact [120].

The AACM metamorphic basement is locally exposed on Wrangel Island (Wrangel Complex), Chukchi and Seward peninsulas $[76,98,99,102,114]$. On Wrangel Island, the metasedimentary and metaigneous rocks of Wrangel Complex are intruded by Neoproterozoic granites (609-677 Ma; [76]). In East Chukotka, basement rocks are metamorphosed to amphibolite facies with documented U$\mathrm{Pb}$ age of orthogneiss of 650-550 Ma [102]. Younger Palaeozoic $\mathrm{U}-\mathrm{Pb}$ ages of inherited zircon cores were yielded from Cretaceous high-grade granitic-metamorphic domes (370-375 Ma; [102]). The overlying Paleozoic and Mesozoic metasedimentary and sedimentary successions are composed of various carbonate (mainly lower Paleozoic sections and the Mississippian Lisburne Group and its analogues) and siliciclastic rocks. Lower Paleozoic rocks in the NE Brooks Range and especially the North Slope subsurface include significant packages of deformed Early Devonian orogenic clastic rocks interpreted to be Caledonian-sourced. Two prominent structural unconformities, (1) Sub-Mississippian and (2) lower Cretaceous (sub-Aptian) document the occurrence of two major orogenic phases across the entire AACM [98-101].

The sub-Mississippian unconformity post-dates Early Devonian deformation (the Romanzof Orogeny of the eastern Brooks Range, see [84]) and is present in all autochthonous and parautochthonous sequences of northern Brooks Range [99, 160]. There is no analogous unconformity known on Wrangel Island, perhaps due to poor exposure. However, as reported by Verzhbitsky et al. [174], the deformation style of Silurian-Lower Devonian rocks is different from the deformation of younger formations that may be an evidence of a separate tectonic phase, perhaps coeval with the Early Devonian deformation in the Northern Alaska.

The sub-Aptian unconformity is well documented in many locations across the Verkhoyansk-Kolyma and Chukotka fold belts, as well as on Kotel'nyi and Bennett islands. It marks cessation of Late Mesozoic orogeny [23, 111, 153]; and references therein). All sedimentary successions of the southern AACM domain were severely affected by this Chukotka-Early Brookian deformation. On the Chukchi Peninsula and probably on Wrangel Island, this orogenic event was followed by uplift and profound erosion between c. 117 and $95 \mathrm{Ma}$ [96]. On the Lisburne Peninsula, the early Brookian largely thin-skinned deformation ended at c. $120 \mathrm{Ma}$ and was followed by extensional exhumation at c. 115-90 Ma [100].

E. Miller with co-authors [96, 97, 160] provided some evidences of the post-Neocomian (post $120 \mathrm{Ma}$ ) Cretaceous extension of the Cukotkan part of the AACM. However, neither scale of this extension, nor its potential causes are not well constrained. In general this extension can be of a back-arc nature with regard to the Late Cretaceous Okhotsk-Chukotka magmatic arc postdated main Neocomian orogenesis.

Tectonic quiescence occurred until the onset of late Brookian deformation at c. 70-60 Ma, which resulted in further uplift of the Brooks Range, and was probably caused by the interaction of the Eurasian, North American and Pacific lithospheric plates [48, 51, 99].

The northern AACM domain is represented by the De Long Massif and by the Arctic Platform. The De Long Massif is inferred to consist of two different zones, or terranes [23]. The Bennett terrane (Bennett Island) reveals a c. 1.5-km-thick succession of weakly deformed and unmetamorphosed Lower Cambrian to Middle Ordovician fossiliferous shales and distal siliciclastic and clastic carbonate turbidites [72, 77]. The Henrietta Terrane (Henrietta and Jeannette islands) is composed of deformed siliciclastic and volcaniclastic rocks and calc-alkaline basalts of island-arc affinity dated as latest Cambrian to earliest Ordovician in age (U-Pb concordia age of detrital zircons by [30]). The section is intruded by diabase and diorite sills and dykes with Ar-Ar age of 440-444 Ma [64] that may suggest a Caledonian magmatic event. This is confirmed by a recent $\mathrm{Ar}-\mathrm{Ar}$ dating of basaltic trachyandesite that provided $419 \pm 3.7 \mathrm{Ma}$ [30]. According to Ershova et al. [30], 
the Henrietta Terrane represents a fragment of an Early Palaeozoic magmatic arc developed on a Neoproterozoic basement in vicinity to Baltica.

The Kotel'nyi Terrane (Kotel'nyi and Bel'kovskii islands in the New Siberian Archipelago) represents a fragment of a Palaeozoic-early Mesozoic passive continental margin that experienced early Cretaceous (Neocomian) compressional deformation. The archipelago was mapped in the 1970s and 1980s, and its geology has been summarized by Kos'ko et al. [75, 77] and Kos'ko [73].

The northern part of the terrane is dominated by 3- to 5-km-thick succession of Middle Ordovician to Middle Devonian lagoonal and shallow-marine fossiliferous limestones, which include basinal carbonate facies in the Lower Silurian and Lower Devonian. The southwestern part is mostly composed of a thick succession of Upper Devonian to lowermost Carboniferous deep-water fine-laminated turbidites, which likely represent a distal margin of this microcontinent.

Carboniferous and Permian sedimentary rocks are absent over most of the terrane except for sporadically occurring tens of meters thick sections of Serpukhovian and Bashkirian shallow water fossiliferous limestones and Lower Permian black shales. A younger section is represented by $0.2-1.3 \mathrm{~km}$ of Triassic to Jurassic marine clay, clayey siltstone, siltstone and sandstone. Both the Carboniferous and Permian strata overlie, with a prominent angular unconformity at their base, Ordovician to Devonian strata. These facts may indicate compressional deformation in earliest Carboniferous time, possibly related to the Ellesmerian orogeny in the Canadian Arctic, which is supported by recent structural observations and sediment provenance study [128].

The Palaeozoic rocks are intruded by numerous sills and dykes of gabbro-diabases that closely resemble in age and composition the Permian/Triassic Tunguska flood basalts [79]. The terrane was intensively compressed in the Early Cretaceous, prior to Aptian, with a clear dextral component.

Detrital zircon study of the upper Palaeozoic rocks revealed dominant Mesoproterozoic to middle Paleozoic detrital zircon populations with almost complete absence of Paleoproterozoic and Archean grains [31, 120]. Therefore, this terrane is very unlikely to have been connected with the Siberian Craton in Palaeozoic.

\section{Sedimentary basins}

As shown above, the consolidated continental crust underlying the Eurasian continental margin formed in Neoproterozoic and much of the Phanerozoic as a result of a series of collisions between the Laurentia, Baltica and Siberia continents and with a number of smaller microcontinents and/or island arc fragments. Sedimentary basins post-dating the major collision mainly formed in response to initial rifting often related to post-orogenic collapse or to spreading episodes and formation of the Eurasia and Amerasia oceanic basins.

The oldest Early Palaeozoic basins formed in the Barents and Timan-Pechora region, and basin formation progressed through the Palaeozoic in the Barents and north Kara shelves, and throughout the Early-Mid Mesozoic in the South Kara Sea and the Yenisei-Khatanga region. The latest phase of basin formation occurs today in the Laptev Sea region, where a series of rift-related basins have been evolving in association with opening of the Eurasia oceanic basin and the development of the present-day boundary between the Eurasian (EUR) and North American (NA) lithospheric plates. Therefore, the basins of the Timan-Pechora and BarentsKara regions rest on continental Neoproterozoic crust and Palaeozoic accreted crust, and are mostly composed of latest Neoproterozoic, Palaeozoic and Mesozoic-Cenozoic carbonate and siliciclastic sequences. Most of the Siberian Arctic basins (the Laptev, East Siberian and Chukchi shelves) are underlain by younger crust of the Late Mesozoic fold belts, and are filled with the Cretaceous (Aptian-Albian and younger) and Cenozoic siliciclastic sediments.

There are over 130 tectonic elements north of the Polar Circle with significant sedimentary accumulations that have not experienced strong compression and therefore can be considered to be sedimentary basins [49]. There are several approaches to classify sedimentary basins [16] and references therein). In this overview, the basins are subdivided into several groups based on the timing of consolidation of their basement. The focus of the below consideration is on offshore Russian Arctic basins especially on those in the Siberian Arctic, where new data allow for updated interpretations.

\section{Barents-Kara region}

Sediment accumulation in the vast Barents and Kara shelves is significant and occurs in a series of large offshore and onshore basins underlain by Neoproterozoic and Palaeozoic crustal tectonic domains (Fig. 6). These basins are much better studied due to an easier access and longer exploration history. Significant geological and geophysical data are presented by Johansen et al. [60], Shipilov and Tarasov [146], Fossum et al. [32], Belonin et al. [5], Henriksen et al. [52], Prishchepa [126], Prishchepa et al. [127], Schenk [141], and Stoupakova et al. [155].

\section{Basins formed on Timanian basement}

The post-Timanian basins dominate the Barens-Kara region and can be grouped into three distinctive tectonic 


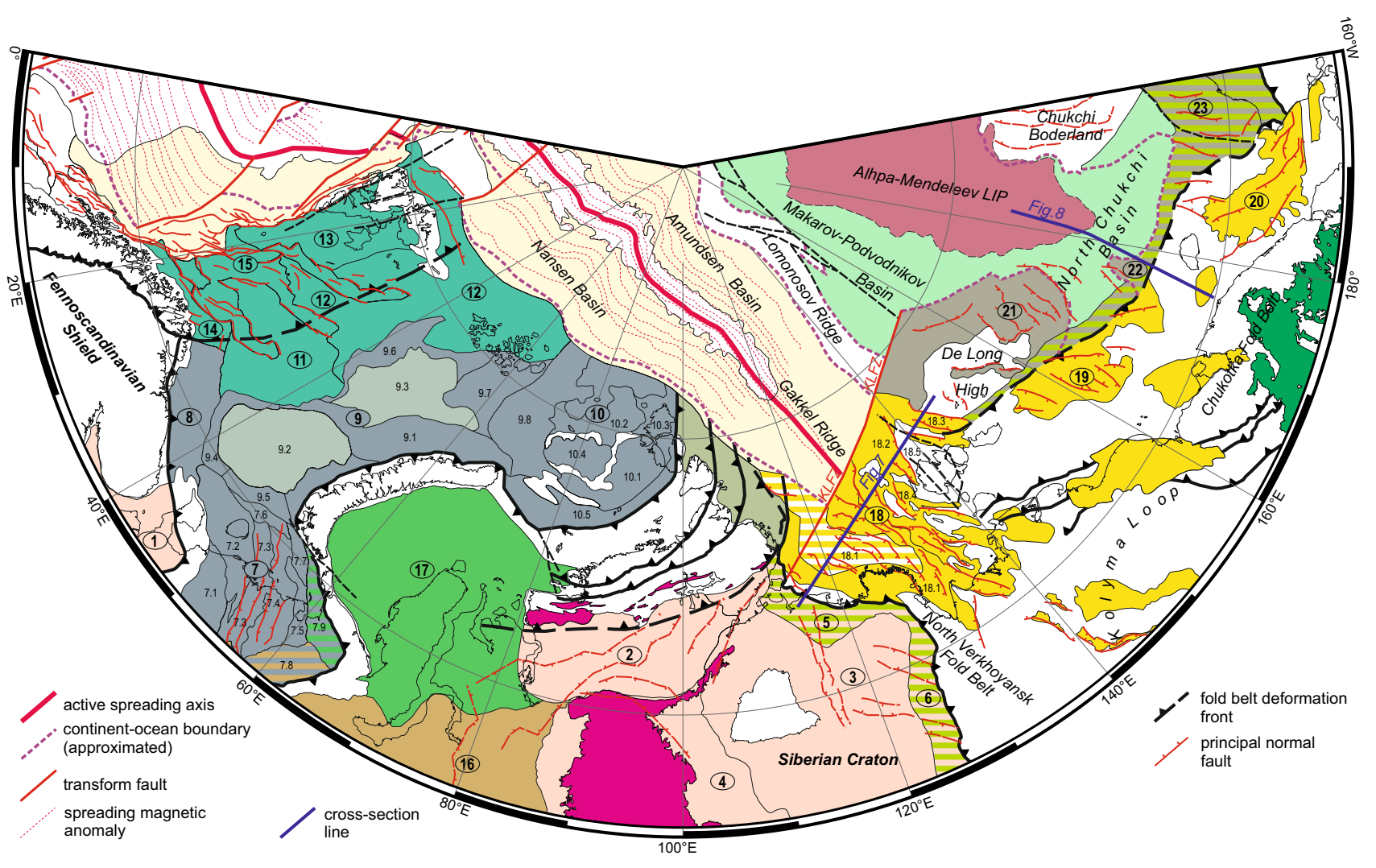

\section{Sedimentary basins}

Pre-Neoproterozoic basins on old cratons (a, Late Mesozoic foreland basins): 1, Mezen'; 2, Yenisei-Khatanga;

3, Olenek-Anabar Anticlise; 4, Kureya-Tunguska Basin; 5, Anabar-Lena Basin; 6, Priverkhoyansk Basin

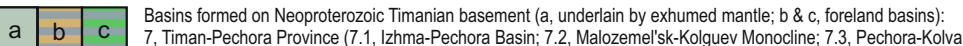

7, Timan-Pechora Province (7.1, Izhma-Pechora Basin; 7.2, Malozemel'sk-Kolguev Monocline; 7.3, Pechora-Kolva Rift;

7.4, Khoreiversk-Pechoromorsk Basin; 7.5, Varandei-Adz'vinsk Zone (Aulacogen); 7.6, Northern Pechoromorsk Monocline;

7.7, South Nov. Zemlya Trough; 7.8, Pre-Uralian Basin; 7.9, Korotaikha Basin); 8, Kola Monocline; 9, East Barents Megatrough

7.7, South Nov. Zemlya Trough; 7.8, Pre-Uralian Basin; 7.9, Korotaikha Basin); 8, Kola Monocline; 9, East Barents Megatrough
9.1, Admiralty-Ludlov High; 9.2, South Barents Basin; 9.3, North Barents Basin; 9.4, Murmansk Slope; 9.5, Kurentsov Slope;

9.6. Northwestern Slope; 9.7 , Al'banov Saddle; 9.8 , St. Anna Trough); 10, North Kara Province (10.1, Uedineniya Basin;

10.2, Urvantsev Basin; 10.3, Sev. Zemlya Basin; 10.4, North Kara Platform (Krasnoarmeisk Basin); 10.5, Northern Taimyr Foreland Basin)

Basins formed on undefined Neoproterozoic to Early Palaeozoic basement of the Arctic Alaska-Chukotka Composite Syperterrane

(a, Late Mesozoic foreland basin): 21, Peri-Delong Basin; 22, New Slberian-Wrangel Foreland Basin; 23, Colville Basin

Basins formed on Early Palaeozoic Caledonian basement: 11, Bjornoya Platform; 12, Kong Karl Platform; 13, Edgeøya Platform;

14, Finnmark Platform; 15, West Barents Rift System

Basins formed on Late Palaeozoic Uralian basement: 16, Northern West Siberian Basin

Basins formed on Early Mesozoic basement: 17, South Kara-Yamal Basin

Basins formed on Late Mesozoic basement (a, zone of hyperextension and mantle exhumation): 18, Laptev Sea Rift System

(18.1, Ust' Lena Rift; 18.2, Anisin Rift; 18.3, New Siberian Rift; 18.4, East Laptev Horst and Graben Province; 18.5, Kotel'nyi High);

19, East Siberian Sea Basin; 20, South Chukchi-Hope Basin

Basins underlain by hyperextended continental crust, exhumed mantle,

and/or oceanic spreading crust along the rim of the Amerasia oceanic basin

Basins underlain by hyperextended continental crust, exhumed mantle,

and/or oceanic spreading crust along the rim of the Eurasia oceanic basin

Early Cretaceous Alpha-Mendeleev Large Igneous

Province

Late Cretaceous Okhotsk-Chukotka supra-subduction

magmatic belt

Fig. 6 Sedimentary basins of the Eurasian Arctic. Location of the map is shown in Fig. 1 
provinces. Two of them, Timan-Pechora and East Barents, bear significant discovered petroleum potential and thus are among the best studied Russian Arctic basins. Geology of the northernmost North Kara province is much less understood due to sparse MCS lines and absence of drilled wells.

The Timan-Pechora Province is composed of a series of NW-trending rift basins, inverted swells and basement highs, such as the Izhma-Pechora Basin (Syneclise), Malozemel'sk-Kolguev Monocline, East-Kolguev Structure Zone, Pechora-Kolva Rift (Aulacogene), Khoreiversk-Pechoromorsk Basin (Syneclise), Northern Pechoromorsk Monocline and Varandei-Adz'vinsk Structural Zone (Aulacogen), and South Novaya Zemlya Trough (Fig. 6). In the northern Pechora Sea, the Timan-Pechora elements are bounded by the North Pechora Sea Monocline transitioning into Kurentsov Slope of the East Barents Megatrough. The sedimentary infill is composed of carbonate, siliciclastic and volcanic rocks of Late Cambrian-Early Ordovician to Quaternary in age. The total thickness of sedimentary section varies from $1-3 \mathrm{~km}$ in the northern Izhma-Pechora Basin to 7-9 km in Pechora-Kolva Rift, and to over $12 \mathrm{~km}$ in the South Novaya Zemlya Trough. Several major regional unconformities subdivide the sedimentary infill into the following main successions reflecting major stages of tectonic activity:

1. Upper Cambrian to Early Devonian dominated by shallow-water carbonate and siliciclastic rocks.

2. Middle to Upper Devonian (Lower Frasnian) composing of predominantly shallow-water siliciclastic rocks.

3. Upper Devonian (Middle Frasnian) to Lower Carboniferous (Tournaisian) shallow-water carbonate and siliciclastic rocks, basinal carbonate and shale (Domanic Formation), reefal buildups.

4. Lower Carboniferous (Visean) to Lower Permian (Artinskian) succession of continental and deltaic coal-bearing rocks (basal part), shallow-water carbonate and evaporite rocks (Middle-Upper Carboniferous interval), and shallow-water limestone-dolomite and basinal shale-marl formations (Lower Permian interval).

5. Lower Permian to Triassic succession of shallow-water and near-shore siliciclastic rocks (Permian interval) and predominately continental molasse formation (Triassic interval).

6. Upper Mesozoic to Cenozoic continental siliciclastic sediments.

The following main tectonic events have contributed into formation of the Timan-Pechora basins:

1. Early Ordovician rifting that shaped the Palaeozoic continental margin of the Baltica continent.
2. Devonian rifting and associated mafic magmatism.

3. Late Palaeozoic inversion associated with the Uralian orogenesis.

4. Mafic magmatism at Permo-Triassic transition and associated uplift, both related to the Siberian Superplume.

5. Late Triassic inversion associated with the Pai-KhoiNovaya Zemlya orogenesis.

The East Barents Megatrough (EBM) dominates the Russian Barents Sea. It extends in the N-S direction for over $1000 \mathrm{~km}$, and in W-E direction for $400-450 \mathrm{~km}$. Tectonically it is limited by steep slopes of the Kola Monocline and the Timan-Pechora tectonic province in the south, by the relatively high-standing basement of the Franz Josef Land Archipelago in the north, by the Bjarmeland and Kong Karls Land platforms in the west, and by the Admiralty basement high and the Novaya Zemlya Fold Belt in the east (Fig. 6). EBM is the most studied among the Russian Arctic offshore basins with 30 offshore exploration wells mostly drilled in 1980s, and about 500,000 km of multichannel seismic reflection (MCS) and long-offset MCS data [63].

The EBM consists of two large depocenters: the South Barents and the North Barents basins, separated by a subdued basement high known as the Ludlov Saddle (Russian tectonic nomenclature). The latter may represent the SW extent of a $650-\mathrm{km}$-long Admiralty High, the largest positive feature in the Russian Barents shelf. Sedimentary thickness of both, the South Barents and the North Barents basins exceeds $20 \mathrm{~km}$. They supposedly formed in middlelate Devonian, probably as a result of back-arc lithospheric extension, and have remained the principal depocenters ever since. As shown by the seismic refraction data $[57,58$, 135] and results of crustal modeling [94], these basins, in their deepest parts, may be floored by exhumed mantle and/ or old oceanic lithosphere.

The EBM's flanks are formed by steep monoclines: the Northwestern, Murmansk and Kurentsov slopes (Fig. 6). The eastern flank between Kurentsov Slope and the Admiralty High is formed by a deformed foreland zone in the front thrusts of the Early Mesozoic Novaya Zemlya Fold Belt and has a complex structure.

MCS data supported by well ties provide a reliable basis for understanding the tectonostratigraphy of the basin. There are five main seismic-stratigraphic units: (1) Cretaceous, (2) Jurassic, and (3) Triassic-upper Permian mostly siliciclastic sequences; (4) Upper Devonian to Early Permian, and (5) Lower Paleozoic syn- and pre-rift clastic and carbonate rocks. The first three are well documented by numerous offshore well penetrations. Beneath unit (4), on the flanks of the megabasin, older pre-rift seismic stratigraphic units visible in seismic data correlate to the Lower Palaeozoic strata of the Timan-Pechora Basin. 
In the extreme NE corner of the Russian Barents between the Franz Josef Land and Novaya Zemlya archipelagos, there is another large sedimentary basin known as the St. Anna Trough (Fig. 6). This feature is slightly separated by the Al'banov-Saddle from the North Barents Basin [67]. The seismic-stratigraphic units of both basins bear the same characteristics, thus, the St. Anna Basin is interpreted to share the same geological history as the EBM and is considered as a part of the latter.

Due to uncertain stratigraphic correlation of the lower seismic horizons, the timing of EBM formation is highly controversial. Proposed models differ significantly with regard to the age of the main rift phase, which varies from Mezo-Neoproterozoic to Permo-Triassic (see [26] for an overview). Zonenshain et al. [181] inferred that the formation of the EMB was related to a Late Devonian episode of back-arc extension along the eastern margin of Baltica related to closure of the PaleoUralian Ocean.

The EBM tectonic history can be described as a succession of the following tectonic regimes [26]:

1. Passive continental margin setting adjacent to the Paleo-Uralian Ocean in Cambrian to Devonian time.

2. Main rift phase accompanied by syn-rift mafic magmatism in a back-arc (?) setting during Mid-Devonian to Early Carboniferous time. This event could have led to hyperextension and mantle exhumation and/or formation of initial oceanic lithosphere in the Northern and Southern depocenters resulting in the separation of a large fragment of the Baltica continental margin that became the Admiralty High.

3. Thermal subsidence in Late Carboniferous and Early Permian time accompanied by formation of carbonate platforms and reefs along the basin's flanks and accumulation of basinal carbonates and shales in its central parts.

4. Rapid subsidence of the entire EBM in late Permian and early Triassic time and accumulation of large volumes of siliciclastic sediments sourced from the Uralian Orogen, and from North Kara/Taimyr. By the end of the Early Triassic, the basin was probably completely filled with clastic sediments.

5. Novaya Zemlya-Pai-Khoi orogenic phase at the latest Triassic and earliest Jurassic times;

6. High Arctic mantle plume-related magmatic event at c. $125 \mathrm{Ma}$ that caused vast eruption of flood basalts [2, $18]$.

Post-Cretaceous sediments are generally absent over most of the EBM. This may be related to tectonic uplift during the Eocene-Oligocene triggered by plate interactions in the North Atlantic and High Arctic, and/or to the recent glacial erosion.
The North Kara Province (NKP) is much less explored part of the Barents-Kara region. Early ideas about its geology were summarised by Shipilov and Tarasov [146], and later by Drachev et al. [26]. Recently, more regional MCS lines were released for publication [58, 92, 93, 103, 172], which provide a better basis for geological interpolations across this still sparsely studied part of the Eurasian Arctic.

Tectonic boundaries of the NKP are defined by the North Siberian Arch in the south, the frontal thrusts of the Taimyr Fold Belt in southeast and east, and by the continent-ocean transition in the north (Fig. 6). Its southern and south-eastern margins are occupied by Northern Taimyr and Novaya Zemlya foreland basins adjacent to the frontal thrusts of the Taimyr and PNZST fold belts. The central part of the NKP is dominated by several depocentres: the Uedineniya Basin, Urvantsev Basin, Severnaya Zemlya Basin, North Kara Platform (Krasnoarmeisk Basin) separated by a series of linear inverted swells (Fig. 6). A large high-standing block of basement, the North Kara High, occurs in the northern part of the province.

Up to $12 \mathrm{~km}$ sedimentary infill of the NKP is inferred to be mostly composed of Palaeozoic carbonate and siliciclastic rocks capped with a much thinner veneer of Mesozoic siliciclastic rocks. The Severnaya Zemlya Archipelago provides excellent exposures of Palaeozoic rocks [46, 90]. Drachev et al. [26], Verzhbitsky et al. [171] and Malyshev et al. [92] used MCS data to extend the stratigraphy of Zevernaya Zemlya to the westerly offshore territory. There are some discrepancies in these interpretations related to the age of the main seismic units and bounding unconformities. However, the following tectonostratigraphic units dominating the NKP offshore basins can be inferred:

1. Early Ordovician syn-rift shallow-marine clastic and volcanic rocks.

2. Ordovician-Silurian post-rift siliciclastic rocks and shales (Ordovician), carbonate and evaporite rocks.

3. Devonian syn-orogenic continental siliciclastic molasses.

4. Carboniferous to Permian siliciclastic sediments coeval with the Taimyr orogeny.

5. Mesozoic to Cenozoic continental and shallow-marine sediments overlying older units with a sharp basal unconformity.

Whether the Neoproterozoic to Cambrian strata are present within the NKP sedimentary basins remains unclear. The detrital zircon age data from the Severnaya Zemlya Archipelago suggests that these sedimentary rocks may rest on Neoproterozoic basement. This is also consistent with unpublished ${ }^{40} \mathrm{Ar}-{ }^{39} \mathrm{Ar}$ and $\mathrm{U}-\mathrm{Pb}$ zircon data from Franz Josef Land, the deepest part of the deep drill 
core on Alexander Island, which give Neoproterozoic ages of the basement (Pease, pers. comm.).

Geological and MCS data suggests multiple structural inversions of the NKP basins related to Mid Palaeozoic Ellesmarian, Late Palaozoic Uralian, and Early Mesozoic Novaya Zemlya orogenies. The latest inversion took place in an Early Cretaceous time and was probably related to far-field stresses associated with Verkhoyansk-ChukotkaBrookian orogenesis.

\section{Basins formed on Caledonian basement}

These basins formed as the result of post-Caledonian crustal extension, and are almost entirely confined to Norwegian Barents Sea (Fig. 6). A large amount of geological and geophysical data was collected in past two decades and is summarized by Smelror et al. [150] and Henriksen et al. [52], and we refer the readers to these works for more detailed information.

The earliest documented extensional event took place in latest Devonian to Early-Middle Carboniferous time and was probably related to collapse of the orogen. It formed a c. 800-km-long trident-shaped rift system crossing western Barents Shelf in NE direction. It divides the Caledonian terrain into two large domains dominated by wide-spread platformal blocks: the northern domain (Kong Karl and Edgeøya platforms and a number of smaller elements such as Olga Basin, Hopen High, Storbanken Anticlines, Sørkapp Basin, and Central Spitsbergen Basin), and a southern domain (Bjornoya and Finnmark platforms and smaller Sentralbanken, Stappen, Gardbarbanken, and Mercurius highs). The West Barents rift system is poorly imaged due to a significant thickness of overburden of Permian to Cretaceous sediments, and some of its elements are only inferred from scarce seismic refraction lines [10, 50]. It is composed of the Nordkapp, Ottar, Fingerdjupet, Maud rift basins, and the Sørkap Graben divided by high-standing basement: the Loppa and Nordsel highs, Polheim Subplatform and a series of smaller highs. The rift system may extend westwards beneath the very thick Jurassic and Cretaceous infill of the Hammerfest, Troms $\varnothing$ and Bjornoya rift basins, which could have also originated in Early Carboniferous [50]. Development of the rift system was accompanied by accumulation of predominantly siliciclastic successions of the Billefjorden Group [177] whose seismic stratigraphy, due to a poor seismic data quality at the lowermost parts of the records, is rather fragmented and poorly understood.

The Permo-Triassic history of the Norwegian Barents shelf was mainly controlled by thermal subsidence and wide-spread accumulation of shallow-water carbonate platforms and evaporates (Late Carboniferous-Early Permian time) and prograding silisiclastic systems sourced from the Uralian Orogen. Renewed extension in Jurassic and Early Cretaceous time was mainly focused in Hammerfest, Troms $\varnothing$ and Bjornoya rifts and generally along the western margin of the present-day Barents Shelf. This history is considered in detail by Henriksen et al. [52].

\section{Basins formed on Early Mesozoic basement}

This category of basins is represented by a large $(800 \times 500 \mathrm{~km})$ NE-SW elongated South Kara Basin (SKB). Generally the basin is fairly well studied seismically and there are five offshore wells that resulted in the discovery of the large Leningranskoe and Rusanovskoe gas condensate fields in the late 1980s, and the Victory oil field in 2014. Summaries of the South Kara geology can be found in Shipilov and Tarasov [146], Stoupakova et al. [155], Ivanova et al. [58], Nikishin et al. [104], and Nikishin [105].

The SKB is located at the hinterland of the Early Mesozoic Novaya Zemlya Fold Belt and is considered to be underlain by structurally complex basement formed at the junction of the Baltican and East Siberian cratons, and the intervening northern termination of the Late Paleozoic Uralides and western flank of Taimyr Fold Belt (Figs. 2, 6). The northern limit of the SKB coincides with the North Siberian Basement Arch, which is the eastern extent of the PNZST fold belt beneath the shelf. The southern limit is not well defined, but may be represented by the large Messoyakha Megaswell in the northern part of the West Siberian Basin. In this case, the N to S extent of the SKB is more than $1000 \mathrm{~km}$.

MCS data reveal a series of SW-NE trending grabens and half-grabens beneath thick post-extension sedimentary cover [58, 104, 105, 175]. Since the sedimentary graben infill has not been tested by drilling, the age of rifting is unconstrained. By analogy with the West Siberian Basin [157], many researchers attribute the SKB rifts to PermoTriassic extension [58, 104, 105, 155]. However, considering the magnitude of the Triassic/Jurassic compression, which resulted in the formation of the PNZST fold belt, it can be inferred that South Kara crustal extension postdates Triassic/Jurassic orogenesis, and could, therefore, have taken place in the Early Jurassic [26]. While this does not preclude the existence of older Permo-Triassic rifts, the latter, however, should have been affected by the Early Mesozoic compression and become a part of the collapsed fold belt underlying the SKB.

The following events are considered to contribute to the formation of the South Kara Basin [26, 175]:

1. Late Carboniferous to Permian collision between Baltica and Siberia along the Urals and Taimyr convergence zones, with trapping of oceanic lithosphere. 
2. Permian/Triassic plume-related magmatic event and crustal extension.

3. Triassic/Jurassic compression and orogeny.

4. Early Jurassic collapse of the Early Mesozoic orogen and formation of grabens at the base of the South Kara Basin.

5. Reactivation of some faults in latest Jurassic and Neocomian, and in Eocene-Oligocene and formation of inverted swells and structural highs.

\section{Siberian Arctic (Laptev, East Siberian Sea and Chukchi shelves)}

The vast Siberian Arctic shelf is significantly less studied than the western Eurasian selves. In the better explored Laptev Shelf, there are c. $50,000 \mathrm{~km}$ of $2 \mathrm{D}$ reflection and refraction seismic lines acquired between 1973 and 2014 . Some seismic data have been published by Ivanova et al. [56], Drachev et al. [28], Franke et al. [35], Sekretov [143], Franke and Hinz [33], and recently by Shkarubo and Zavarzina [147], Zavarzina et al. [178], Shkarubo et al. [148]. The East Siberian Shelf was the least studied until 2012 with only a few MCS lines available [23]. The Russian Chukchi Sea had much better seismic coverage [122, 170]. Between 2012 and 2014, there was a significant increase in long-offset MCS data acquisition by TGS, DMNG, and ION seismic companies, the results of remain largely unreleased. All these data in combination with the publically available gravity and magnetic field data provide a reliable basis for unraveling structure and tectonic history of this large offshore territory.

The Siberian Arctic houses two families of basins. The basins located south of the Late Mesozoic frontal thrusts and resting on the southern margin of the AACM are inferred to be filled with Cretaceous and Cenozoic sediments postdating the major Verkhoyansk-Chukotka-Brookian orogeny. The basins located north of the frontal thrust zone are likely underlain by older AACM domain, which was not involved in Late Mesozoic orogeny [23].

\section{Basins formed on Late Mesozoic basement}

Basins underlain by collapsed parts of the vast Verkhoyansk-Kolyma-Chukotka orogen are mainly located offshore between the Taimyr Peninsula and Alaska (Fig. 6). The majority of them formed in a rift and post-rift setting, and was later modified through a series of inversions. Comprehensive reviews of these basins were published recently by Grantz et al. [49], Drachev et al. [26], Drachev [23].

Laptev Sea Rift System (LRS) The Laptev Shelf represents an extensive, $500 \mathrm{~km}$ wide and $700 \mathrm{~km}$ long, rift system, which has been developing since at least Late Cretaceous. Its formation is caused by the divergent movement between Eurasian and North American lithospheric plates, which resulted in the breakup of continental lithosphere and the formation of the Eurasia oceanic spreading basin [45, 137]. Many details on structure and seismic stratigraphy of the LRS were published by Drachev et al. [28], Sekretov [143], Franke et al. [35], and Franke and Hinz [33, 34].

The LRS consists of several wide rift basins and relatively narrow rifts separated by high-standing blocks of underlying Late Mesozoic basement. The following main structural elements were identified (from west to east): the Ust' Lena, Anisin and Bel'kov rifts and the East Laptev, Stolbovoi, Shiroston and Kotel'nyi high-standing blocks, or horsts. The easternmost New Siberian Rift is located in the northwestern part of the East Siberian Shelf between the high-standing Kotel'nyi and De Long blocks of the prerift basement.

The rift basins are controlled by a series of large-offset listric normal faults, and are generally asymmetric. Main extensional detachments located at the eastern shoulders of the rifts are documented for the Anisin and the Bel'kov rifts. The Ust' Lena Rift, dominating the central and western Laptev Shelf, has a more complex structure. Franke et al. [35] suggested that this rift along its entire N$\mathrm{S}$ extent is bounded from the east by a major detachmentthe M/V Lazarev Fault. However, some MCS lines indicate the detachment location is in the western flank of the rift, suggesting the rift is probably segmented along its strike [28].

The total thickness of the strata infilling the rifts is typically c. $3-8 \mathrm{~km}$, reaching $13-15 \mathrm{~km}$, and perhaps up to $18 \mathrm{~km}$, in the deepest part of the Ust' Lena Rift. On the basement highs, the thickness is reduced to $1-2 \mathrm{~km}$ or less. This fact, combined with the apparent eastward decrease in structural complexity of the rifts, allowed Drachev et al. [28] to infer an eastward migration of rifting linked to the migration of the Gakkel Ridge spreading axis in the same direction along the inferred Khatanga-Lomonosov Fracture Zone (Fig. 6). However, recent (but unpublished) higher quality MCS data acquired by ION and TGS seismic companies shows $>16 \mathrm{~km}$ of sedimentary infill in the Ust' Lena Rift but a lack of large-offset listric normal faults within its interior (the latter supposedly required to produce the significant crustal thinning needed to accommodate such enormous thickness of sediments). These two observations favor another model, one in which most of the central and eastern parts of the LRS, and its south-western and western (near-Taimyr) flanks are considered to be an area of initial extension associated with crustal stretching (e.g., [121]). The deep Ust' Lena Rift can be characterized as a zone of hyperextension - the result of thinning, with 


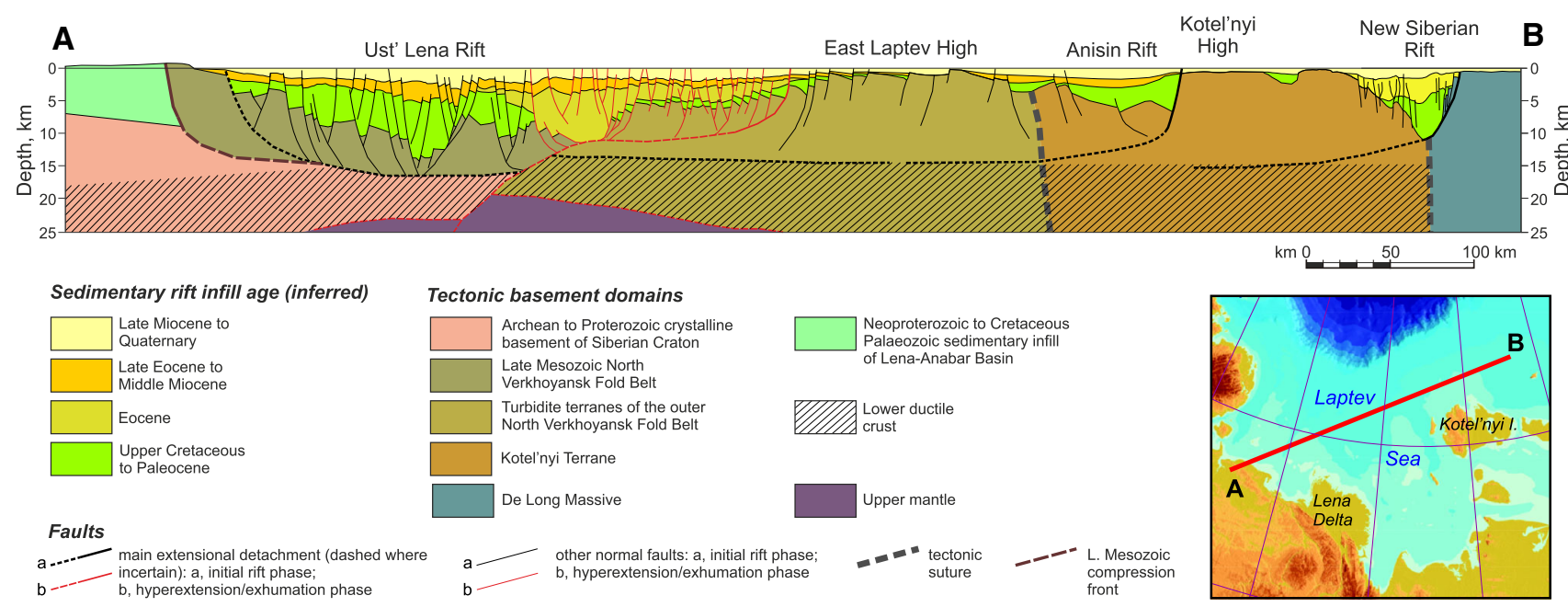

Fig. 7 Schematic cross-section illustrating crustal architecture of the Laptev Rift System. Based on published [28, 35, 147] and unpublished MSC data. For the location see inserted map and Fig. 1

much greater lithospheric extension mostly concentrated in the ductile lower crust and upper mantle with both directly underlying synrift sediments. The axial zone of the Ust' Lena Rift with sediment thickness exceeding 16-18 km can be interpreted as a mantle exhumation zone (Fig. 7).

The timing of initial extension (stretching), thinning and exhumation are poorly constrained due to the absence of deep offshore well penetrations (see [23] for review of different seismic stratigraphic concepts). Based on the assumption that the rifting could have started as early as the Late Cretaceous, and on stratigraphic control from onshore grabens in the area of the Lena River Delta, northern Verkhoyansk Mountains, and in the Yana-Indigirka Lowland [28]; Kos'ko and Trufanov [74], the following sequence of events can be proposed for the formation of the LRS:

1. C. $130-125 \mathrm{Ma}-$ Verkhoyansk orogeny.

2. C. $90-80 \mathrm{Ma}-$ onset of initial (stretching) phase of crustal extension across the Laptev Shelf resulted in formation of the main structural elements of the LRS.

3. C. $70-60 \mathrm{Ma}-$ onset of the hyperextension (thinning) phase mostly concentrated in the western Laptev (Ust' Lena Rift) and in the easternmost Anisin and New Siberian rifts.

4. C. $60-55 \mathrm{Ma}-$ possible mantle exhumation in northern part of the Ust' Lena Rift and continental breakup along the strike of the Barents-Kara continental margin.

5. 55-c. $20 \mathrm{Ma}$ - significant reduction or cessation of the extensional regime across the LRS.

6. C. 20-15 Ma-onset of recent extension regime related to modern divergent boundary between Eurasia and North American plates.
A long period of tectonic quiescence across the Laptev Shelf between $55 \mathrm{Ma}$ crustal breakup and resuming of the extension around $15 \mathrm{Ma}$ inferred to have been caused by the accommodation of the Eurasia Basin opening by the Khatanga-Lomonosov Fracture Zone, prevented penetration of extensional strain into the Laptev Shelf [23].

Basins of central East Siberian Sea and southern Chukchi Sea There are three large sedimentary basins mapped in this part of the Siberian Shelf: East Siberian Sea, New Siberian-Wrangel and South Chukchi (Hope) basins (Fig. 6).

The East Siberian Sea Basin (ESSB), or the East Siberian Depocenter of Franke et al. [36], is located in the central part of the East Siberian Sea shelf and is slightly elongated in NW-SE direction (Fig. 6). The basin reveals an asymmetric profile with a gently north-dipping southern flank and a steeper and narrower northern flank adjacent to the De Long High. The basin is filled with up to $8 \mathrm{~km}$ of siliciclastic sediments resting on Late Mesozoic collapsed fold belt. The maximum total infill thickness probably exceeds $10 \mathrm{~km}$ at the deepest part of the basin.

Structural style of the ESSB is dominated by a large number of relatively small-offset normal faults varying in their geometries from single listric faults to sub-vertical wrench faults and to complex arrays of these faults. It differs significantly from extensional structure of the rifted Laptev Shelf and is interpreted as transtensional [23, 33, 36]. A possible cause for the transtensional regime could be inferred from the basin's tectonic setting within a broad region of Early Cenozoic crustal re-adjustment between the large NA and EUR lithospheric plates. 
The age of the basin sediment infill is generally regarded as Lower Cretaceous (Aptian-Albian) to Quaternary [23, $36,74]$. A sharp unconformity subdivides the infill into the lower seismic-stratigraphic package consisting of pre- and syn-kinematic sedimentary successions, and an upper package that is largely unaffected by faulting. The age of these packages is disputed. If the successions can be correlated with onshore strata, then a Cenomanian-Turonian to Paleocene age can be inferred for the pre-kinematic unit, an Eocene to Middle Miocene age for the syn-kinematic unit, and a Late Miocene to Quaternary age for the post-kinematic unit.

The tectonic history of the ESSB is characterized by the following stages [23]:

1. Tectonically "quiet" platformal regime during Late Cretaceous and Paleocene with wide-spread deltaic and fluvial depositional environments.

2. Rapid subsidence of the basin during Eocene to Early/ Middle Miocene in a transtensional setting controlled by dextral divergence of the NA and EUR plates. At the end-Oligocene-Early Miocene time a change in plate interaction caused slight compression and basin inversion.

3. Complete termination of active tectonism over the entire East Siberian Sea in the Late Miocene to Pleistocene as the main zone of interaction between the EUR and NA plates moved to the Laptev Shelf.

The New Siberian-Wrangel Foreland Basin occurs north of the frontal deformation zone [26]. It is a narrow westeast trending basin in the East Siberian Shelf extending and widening north of Wrangel Island and possibly merging into the Colville Foreland Basin in the US Chukchi Sea (Fig. 6). Most of the basin infill is represented by a wedgeshaped seismic unit that increases in thickness towards the deformational front. Its age is inferred as Late Jurassic to Early Cretaceous (pre-Aptian), by analogy with the better known onshore Late Mesozoic foreland basins [23]. A prominent seismic unconformity at the base of this unit is interpreted to reflect the onset of the main orogenic phase, which occurred on the Chukchi Peninsula around Hauterivian-Barremian time $[152,153]$. The MCS lines show compressional folds associated with the frontal thrust zone affecting the lower section of the basin's infill, which is inferred to be composed of siliciclastic coal-bearing sediments deposited during terminal stages of the ChukotkanBrookian orogeny in the Early to Late Cretaceous time.

The South Chukchi Basin (Hope Basin in the US sector) extends east-southeast for over $1000 \mathrm{~km}$ from Wrangel Island up to the Kotzebue Sound Bay in the Western Alaska (Fig. 6). Its structure and stratigraphy was described by Pol'kin [124], Verzhbitsky et al. [170, 173], Petrovskaya et al. [122], Drachev et al. [26], Drachev [23].
The US Hope Basin was characterized by Tolson [159] and by Klemperer et al. [68].

The northern basin's flank is limited by the transpressional Wrangel-Herald basement arch, while the southern flank formed by onlap of sediments onto the deformed Late Mesozoic basement along the Chukotkan coast. The MCS data show that the South Chukchi Basin has clearly asymmetric profile. Its southern limb is formed by a gentle southward rise of the basement, while the northern limit is represented by a steep fractured zone at the junction with the Wrangel-Herald Arch. The internal structure of the basin is dominated by a series of NW-SE trending grabens, half-grabens and horsts, whose assemblage was characterized as transtensional [159, 173]. Many faults demonstrate a later inversion. The gravity data shows an apparent link between the basin and the Kobuk dextral strike-slip fault that, with the latter providing required transpression regime at its westernmost termination.

The basin infill thickness varies between 2 and $4 \mathrm{~km}$ and probably not exceeding $5-6 \mathrm{~km}$ in the deepest part of the basin (Klemperer et al. [68, 173]. The stratigraphic age of the sediments is poorly constrained, but there is a general consent that it may be of Early Cretaceous (Aptian-Albian) to Quaternary range. Cretaceous and Paleocene sediments were not revealed by the drilled wells in the US sector, and are commonly absent onshore Chukotka, which may be a result of widespread erosion during the latest CretaceousPaleocene in a compressional plate tectonic setting. Yet, Upper Cretaceous sediments can be present in the deepest offshore parts of the basin.

The following tectonic phases are inferred for the South Chukchi-Hope Basins:

1. The initial rifting associated with the orogenic collapse in Cretaceous and Palaeocene.

2. The main subsidence phase in transtensional tectonic regime resulted from dextral relative movements between the NA and EUR plates in Eocene and probably early Oligocene.

3. The compressional inversion driven by the NW-SE plate convergence in Oligocene-Miocene [51]. This was also time of the major transpressional growth of the Wrangel-Herald Arch and reactivation of the Late Mesozoic Brookian-Chukotkan fold belt front.

Basins formed on hyperextended crust and/or exhumed mantle in the northern parts of the East Siberian and Chukchi seas

The northern part of the East Siberian Sea has, until recently, remained a virtually unexplored area. Its structure has mainly been inferred from potential field data. A series of closely spaced SSE-trending linear and rhomboid 
gravity lows east of the De Long High were interpreted by Fujita and Cook [37], Kos'ko et al. [75], Drachev et al. [25, 26] as evidence of an extensional crustal assemblage named the Vil'kitskii Trough, or Vil'kitskii Rift System. In the northern Chukchi Sea (north of Wrangel Island), first MCS seismic lines [47] allowed to reveal a very deep North Chukchi sedimentary basin $(\mathrm{NChB})$, which was then confirmed by more extensive regional MCS surveys [122, 170].

In 2009, first seismic refraction line was acquired by the Russian seismic company SevMorGeo west of Wrangel Island [136], and in 2012 first long-offset regional MCS surveys were conducted by ION Geophysical Company. These data provide an unprecedented image of the NChB and its western extent onto the northern East Siberian Sea. On these lines, this vast sedimentary basin is clearly recognized to be underlain by apparently exhumed mantle.

The NChB in its current outline extends for c. $850 \mathrm{~km}$ from the area east of the De Long Archipelago to US Chukchi Sea (Fig. 6). Its deepest part is located north of Wrangel Island where it coincides with a prominent gravity low. The eastern flank of the basin in the US Chukchi Sector is limited by the north trending Chukchi High, and the western flank corresponds to the rifted margin of the De Long High.

The seismic refraction data provide a complete section of the basin (Fig. 8). It extends north up to the shelf brake.
Thickness of the sedimentary infill reaches $20 \mathrm{~km}$ in the axial part of the basin. Its internal structure is asymmetric and relatively simple, with steep southern (Hinge Line by [48] and gentle northern limbs and a flat base. The consolidated crust below the sedimentary infill in the depocentre is thin, not more than $8 \mathrm{~km}$, with seismic velocities from 6.5 to $6.8 \mathrm{~km}$, consistent with serpentinized mantle.

The sedimentary infill is apparently dominated by siliciclastic sedimentary rocks. It is divided by a prominent unconformity, which is a major seismic downlap surface, into two megasequences dominated by well-developed clinoforms. The lower one spans c. 2/3rd of the total basin infill, and reveals a strong progradation towards north and NE. The upper one is c. $5 \mathrm{~km}$ thick in the central basin, and is dominated by the north-prograding clinoforms.

There are two main opinions about the age of the basin's infill: (1) post-Devonian, by analogy with the North Slope of Arctic Alaska [15, 122, 136], and (2) Cretaceous to Cenozoic [23, 26, 48, 170]. The latter is supported by correlation of the sharp unconformity in the base of the section along the southern flank of the basin with the basal unconformity of the adjacent New Siberian-Wrangel Foreland Basin, which, in turn, corresponds to the major Lower Cretaceous Unconformity (LCU) of the Arctic Alaska [23]. Another reliable constraint on the timing of deposition of the lower section of the NChB is a clear onlap

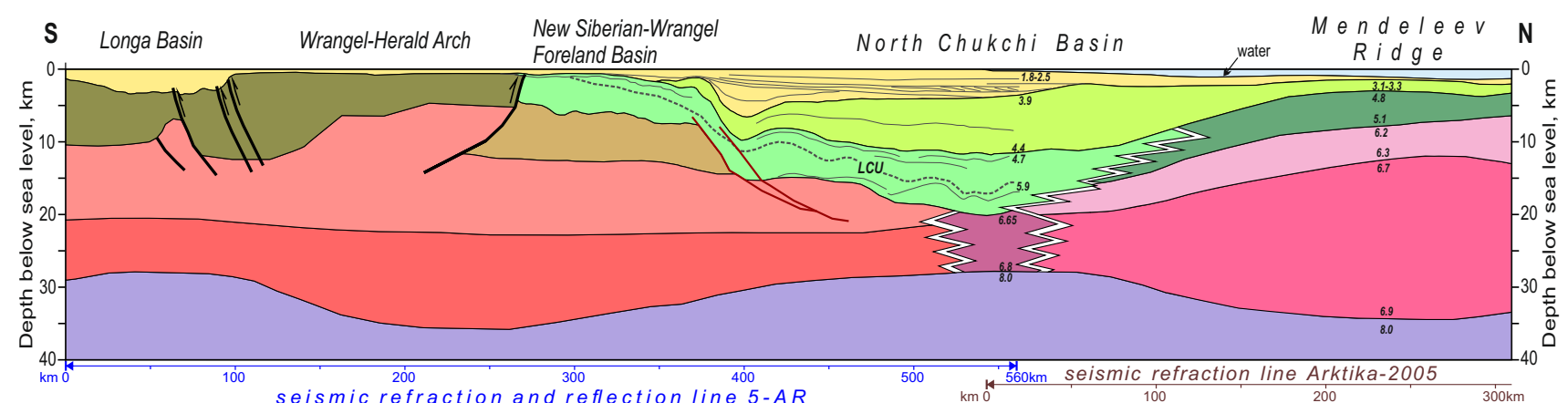

Continental realm

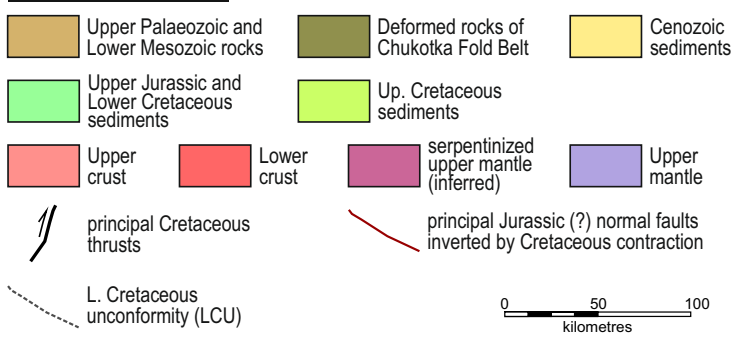

Fig. 8 Schematic cross-section illustrating crustal architecture of the North Chukchi Basin and adjacent shelf to the west and NW of Wrangel Island. Based on published MCS reflection and refraction
Alpha-Mendeleev Volcanic Province
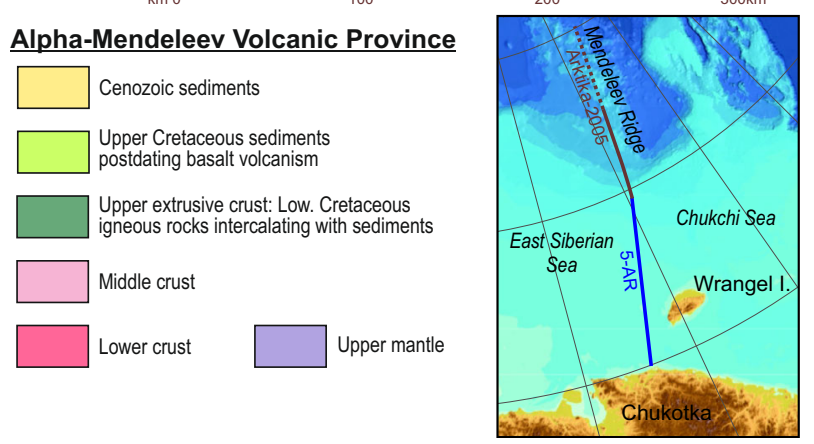

data $[125,136]$. The bold italic Latin numerals represent seismic $\mathrm{P}$-wave velocities in $\mathrm{km}$ per second. For the location see inserted map and Fig. 1 
of the lowermost clinoforms onto magmatic basement of the Mendeleev Ridge along the northern flank of the basin, documented by AWI-2008 seismic lines and seismic Arktika-2005 transect $[62,125]$. Assuming formation of the Alpha-Mendeleev LIP is related to the c. 125 Ma magmatic plume event $[18,27]$, the lower prograding succession of the NChB may be of Aptian-Albian age, and could be correlative in time with the major Brookian-Cukotka orogeny. The downlap surface at the base of the upper section is roughly correlative with the Mid Brookian Unconformity (MBU) in the US Chukchi Sea (Cretaceous/Cenozoic transition).

\section{Discussion}

Vast epicontinental shelves of the Eurasian Arctic represent perhaps the most complex geological system globally. Their remoteness and harshness have always been hampering field works, and existing geological models have been suffering from deficit of new data, which would allow for their verification. Recent years have, however, been marked with significant progress in new data acquisition, both onshore and offshore, including most remote Siberian Arctic islands.

Two datasets in particular, play perhaps the most important role in recent advances in Arctic geology. Firstly, new offshore MCS data has been continuously collected over the past decade, which has been seeing the most profound reduction of the ice cover, especially in the Siberian and Alaskan Arctic regions. This has permitted acquisition of high-quality seismic data with long streamers that record to the Moho. Secondly, the advent of $\mathrm{U}-\mathrm{Pb}$ geochronology, which became a routine method for determining the age of minerals and rocks, has resulted in tremendous amount of new zircon age data from both igneous and sedimentary rocks. This data has started to reveal previously unknown links between terranes now scattered vast distances across the Arctic region.

In light of these two datasets, three categories of scientific problems are currently being addressed:

1. The offshore extents and relationships of the Arctic fold belts beneath sedimentary basins.

2. The nature of the sedimentary basins and their underlying crust.

3. The palaeogeographic and tectonic links between various terranes, especially those surrounding the deep-water Amerasia basin.

The former two requires integration of modern highquality geophysical datasets, especially the deep crustal seismic refraction data with gravity and magnetic data. There is been a significant progress achieved in this direction in the Barents Sea region $[69,94]$ and references therein), while in the more remote Siberian Arctic these data are still scarce.

In the Kara Sea region, the most challenging puzzle is the offshore extent of the Uralian fold belt and its relationship with the younger Pai-Khoi and Novaya Zemlya fold belts (PNZST fold belt in this paper) beneath northern West Siberian and South Kara basins. The proposed model (Figs. 2, 3) is based on areal extent of the known compressional deformations of Triassic rocks, and depicts a rather large crustal domain affected by these deformations. While implication of the trapped oceanic slab roll-back model (see above) may explain some important features of the PNZST, it cannot be applied for the areas outside of the South Kara. Therefore, another cause of the late Triassic/ early Jurassic deformation needs to be proposed. Perhaps it may be related to a northern push of the Siberian Craton by its collision, as a part of Laurasia, with the Cimmeria Continent at the end-Triassic [144].

Presence of hyperextended rifted basins under the Arctic shelves, revealed by the modern seismic data, has not been previously discussed and thus represents a new problem. The amount, direction and timing of hyperextension, especially in the Laptev and northern Chukchi-northern East Siberian shelves is yet to be addressed, primarily through acquisition of new deep crustal refraction seismic data.

Palaeo-tectonic relationships between the Siberian Arctic terranes (i.e., North Kara, Kotel'nyi, Wrangel, Bennett and Henrietta terranes) with the other Arctic tectonic provinces have become a major focus of several recent international efforts. This is a very active area of research underpinned by recent $\mathrm{U}-\mathrm{Pb}$ age dating of various detrital zircon populations [29-31, 72, 82, 98, 101, 120, $179]$, and by very limited paleomagnetic results [95, 168]. Two main concepts are being discussed: (1) Neoproterozoic Baltica affinity many of these terranes; (2) their origin from a dismembered Precambrian continent (based on an earlier Arctida concept of [181]; e.g., [169]). More data are being analyzed as was shown at the recent AAPG 3P Arctic conference in Stavanger (http://www.3parctic.com).

\section{Conclusion}

The vast Eurasian Arctic epicontinental shelf and adjoining mainland reveals a very complex structure and tectonic history resulting from a series of first-order continentcontinent collisions and accretion of large microcontinents and island-arc fragments during Neoproterozoic and Phanerozoic. Figure 9 illustrates temporal and spacial interplay of main tectonic regimes across the Eurasian Arctic in Phanerozoic. After their formation, the Eurasian fold belts were further subjected to crustal extension, which 


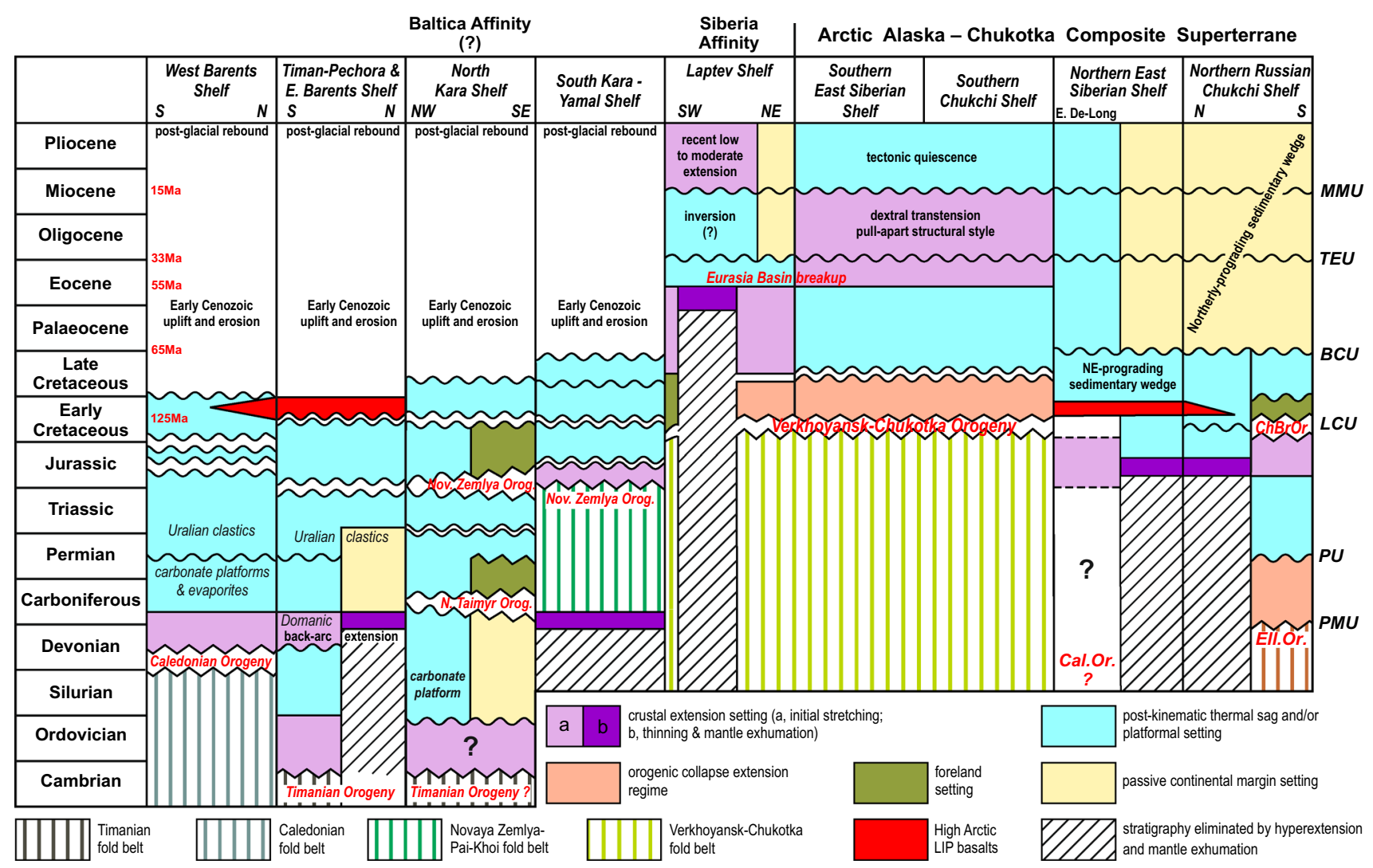

Fig. 9 Tectonic regimes and events dominated the Eurasian Arctic shelf development during Phanerozoic. Major unconformities within sedimentary basins: MMU, Mid Miocene; TEU, Top Eocene; BCU, base Cenozoic (Mid Brookian in Arctic Alaska); LCU/BU, Lower Cretaceous; LPU, Lower Permian; PMU, Pre-Mississippian.

gave birth to large sedimentary basins masking the northern terminations of the fold belts. The later stages of the extension are associated with breakup of Pangea and Eurasia and culminated in ocean formation. The resulting highly complex geological system has been challenging geoscientists ever since the first pioneering geological expeditions to the Arctic islands and the ocean. At least two (Permo-Triassic and Aptian) mantle plume events resulted in underplating and weakening of pre-existing lithosphere. Large areas of submarine, hyperextended continental crust and exhumed mantle developed along the Amerasia Basin margins especially in the northern East Siberian and Chukchi seas.

Over past decade, there is been considerable progress in geophysical and geological data acquisition in both onshore and offshore Arctic territories, briefly summarized above. Many questions have been resolved, but many still remain unanswered. The latter include:

- The timing and plate kinematics associated with Amerasia Basin formation (not discussed in this paper).

- The offshore extent of the Caledonides and Timanides.
Abbreviated words in red: ChBrOr, Chukotkan-Brookian Orogeny; Ell.Or., Ellesmerian Orogeny; Cal.Or., Caledonian Orogeny; Nov. Zemlya Orog., Novaya Zemlya Orogeny; N. Taimyr Orog., Northern Taimyr Orogeny

- The location of the Uralian fold belt beneath the thick sedimentary cover in the northern West Siberia region and its relationship to the Late Paleozoic Taimyr fold belt.

- The offshore extent of the Early Mesozoic Pai-KhoiNovaya Zemlya-South Taimyr fold belt, and mechanism(s) of its formation.

- The relationship of the De Long Massif terranes with Kotel'nyi Island geology.

- The scale and mechanism of post-orogenic extension on the Chukotka Peninsula and in the adjacent areas (not discussed above).

- The occurrence of Caledonian/Ellesmerian-age deformation on Wrangel Island, the New Siberian Islands and in the Severnaya Zemlya Archipelago.

- The offshore extent of the South Anyui Suture.

Further progress in understanding Arctic lithosphere evolution will be especially advanced by new investigations of Arctic islands, as well as by offshore long-offset refraction and reflection seismic surveys, sampling and drilling campaigns. 
Acknowledgments I am grateful to Prof. Victoria Pease, Prof. Andrei Khudolei, and to an anonymous reviewer for very helpful comments and suggested changes to the manuscript. My wife Elena Miloradovskaya (Karasik) assisted with editing the text and verifying the references.

\section{References}

1. Amato JM, Toro J, Akinin VV, Hampton BA, Salnikov AS, Tuchkova MI (2015) Tectonic evolution of the Mesozoic South Anyui suture zone, eastern Russia: a critical component of palaeogeographic reconstructions of the Arctic region. Geosphere, vol 11, no 5 (in press)

2. Amundsen H, Evdokimov A, Dibner V, Andresen A (1998) Petrogenetic significance and evolution of Mesozoic magmatism, Franz Josef Land and the Barents Sea. In: Solheim A, Musatov E, Heintz N (eds) Geological aspects of Franz Josef Land and the Northernmost Barents Sea (the Northern Barents Sea Geotraverse). Norsk Polarinstitutt, Meddelelser, p 151

3. Andreichev (2010) Evolution of the Timan-Pechora basement based on isotopic-geochronological data. Doctor of geological and mineralogical sciences, Thesis synopsis, Institute of Geology and Geochemistry, Uralian Branch of Russian Academy of Sciences, Ekaterinburg (in Russian)

4. Bea F, Fershtater G, Montero P (2002) Granitoids of the Uralides: implications for the evolution of the Orogen. In: Brown D, Juhlin C, Puchkov V (eds) Mountain building in the Uralides: Pangea to the present. AGU Geophysical Monograph Series, 132, pp 211-232

5. Belonin MD, Prishchepa OM, Teplov EL, Budanov GF, Danilevskii SA (2004) The Timan-Pechora province: geology, hydrocarbon potential and development prospects. Nedra, St. Petersburg (in Russian)

6. Beliakova LT, Stepanenko VJ (1991) Magmatism and geodynamics of the Baikalide basement of the Pechora syneclise. Izv AN SSSR Ser Geol 12:106-117 (in Russian)

7. Bezzubtsev VV, Zalyaleev RSh, Goncharov YI (1986) Geological map of mountain Taimyr, scale 1:500,000. Explanatory notes, Krasnoyarsk (in Russian)

8. Bogolepova OK, Gee D (2004) Early Paleozoic unconformity across the Timanides, NW Russia. In: Gee D, Pease V (eds) The Neoproterozoic Timanide Orogen of Eastern Baltica. Geological Society, London, Memoirs, 30, pp 145-158

9. Bondarev VI (ed) (1982) Geology of the south island of Novaya Zemlya. PGO 'Sevmorgeologiya', Leningrad

10. Breivik AJ, Gudlaugsson ST, Faleide JI (1995) Ottar Basin, SW Barents Sea: a major Upper Palaeozoic rift basin containing large volumes of deeply buried salt. Basin Res 7(299):312

11. Breivik AJ, Mjelde R et al (2002) A possible Caledonian arm through the Barents Sea images by OBS data. Tectonophysics 355:67-97

12. Brown D, Juhlin C, Puchkov V (eds) (2002) Mountain building in the Uralides: Pangea to present. Geophysical Monograph Series. American Geophysical Union, Washington, DC, 132

13. Brown D, Puchkov V, Alvarez-Marron J, Bea F, Perez-Estaún A (2006) Tectonic processes in the Southern and Middle Urals: an overview. In: Gee DG, Stephenson RA (eds) European lithosphere dynamics. Geological Society, London, Memoirs, 32, pp 407-420

14. Bulgakova MD, Kolodeznikov II (1990) Middle Paleozoic Rifting on the north-east of USSR: sedimentogenesis and volcanism. Nauka, Moscow (in Russian)

15. Burlin YuK, Shipel'kevich YV (2006) Principal features of the tectonic evolution of sedimentary basins in the Western Chukchi shelf and their petroleum resource potential. Geotectonics 40:135-149

16. Busby C, Azor A (eds) (2012) Tectonics of sedimentary basins: recent advances. Wiley-Blackwell, London

17. Corfu F, Svensen H, Neumann E-R, Nakrem HA, Planke S (2010) U-Pb and geochemical evidence for a Cryogenian magmatic arc in central Novaya Zemlya, Arctic Russia. Terra Nova 22:116-124

18. Corfu F, Polteau S, Planke S, Faleide JI, Svensen H, Zayoncheck A, Stolbov N (2013) U-Pb geochronology of cretaceous magmatism on svalbard and Franz Josef Land, Barents Sea Large Igneous Province. Geol Mag 150:127-1135

19. Corfu F, Gasser D, Chew DM (eds) (2014a) New perspectives on the Caledonides of Scandinavia and related areas. Geological Society, London, Special Publications, 390, pp 1-8

20. Corfu F, Andersen TB, Gasser D (2014b) The Scandinavian Caledonides: main features, conceptual advances and critical questions. In: Corfu F, Gasser D, Chew DM (eds) New perspectives on the Caledonides of Scandinavia and related areas. Geological Society, London, Special Publications, 390, pp 9-43

21. Dobrzhinetskaya LF, Eide EA et al (1995) Microdiamond in high-grade metamorphic rocks of the Western Gneiss Region, Norway. Geology 23:597-600

22. Dovzhikova E, Pease V, Remizov D (2004) Neoproterozoic island arc magmatism beneath the Pechora Basin, NW Russia. GFF 126:353-362

23. Drachev SS (2011) Tectonic setting, structure and petroleum geology of the Siberian Arctic offshore sedimentary basins. In: Spencer AM, Embry AF, Gautier DL, Stoupakova AV, Sørensen K (eds) Arctic petroleum geology. Geological Society (London) Memoirs, 35, 369-394

24. Drachev SS, Savostin LA (1993) Ophiolites of Bol'shoi Lyakhov Island (New Siberian Islands). Geotektonika 6:33-51 (in Russian)

25. Drachev SS, Johnson GL, Laxon S, McAdoo D, Kassens H (1999) Main structural elements of the Eastern Russian Arctic Continental Margin derived from satellite gravity and multichannel seismic reflection data. In: Kassens H, Bauch HA et al (eds) Land-Ocean Systems in the Siberian Arctic: dynamics and history. Springer, Berlin, pp 667-682

26. Drachev SS, Malyshev NA, Nikishin AM (2010) Tectonic history and petroleum geology of the Russian Arctic Shelves: an overview. In: Vining BA, Pickering SC (eds) Petroleum geology: from mature basins to new frontiers-Proceedings of the 7th Petroleum Geology Conference. Geological Society, London, pp 591-619

27. Drachev SS, Saunders A (2006) The Early Cretaceous Arctic LIP: its geodynamic setting and implications for Canada Basin opening. In: Scott RA, Thurston DK (eds) Proceedings of the Fourth International Conference on Arctic Margins, Dartmouth, Nova Scotia, 30 September to 3 October. U. Department of the Interior, Anchorage, Alaska, pp 216-223

28. Drachev SS, Savostin LA, Groshev VG, Bruni IE (1998) Structure and geology of the continental shelf of the Laptev Sea, Eastern Russian Arctic. Tectonophysics 298:357-393

29. Ershova VB, Prokopiev AV, Nikishin VA, Khudoley AK, Malyshev NA, Nikishin AM (2015) New data on Upper Carboniferous Lower Permian deposits of Bol'shevik Island, Severnaya Zemlya Archipelago. Polar Res 2015(34):24558. doi:10. 3402/polar.v34.24558

30. Ershova VB, Lorenz H, Prokopiev AV, Sobolev NN, Khudoley AK, Petrov EO, Estrada S, Sergeev S, Larionov A, Thomsen TB (2015b) The De Long Islands: a missing link in unraveling the Paleozoic paleogeography of the Arctic. Gondwana Research (in press) 
31. Ershova VB, Prokopiev AV, Khudoley AK (2015c). DevonianPermian sedimentary basis and paleogeography of Russian Eastern Arctic. In: AAPG 3P Arctic Conference abstract volume. Stavanger, pp 70-71

32. Fossum BJ, Schmidt WJ, Jenkins DA, Bogatsky VL, Rappoport BI (2001) New frontiers for hydrocarbon production in the Timan-Pechora Basin, Russia. In: Downey MW, Threet JC, Morgans WA (eds) Petroleum provinces of the twenty-first century, vol. Memoirs, 74, American Association of Petroleum Geologists, Tulsa, pp 259-279

33. Franke D, Hinz K (2005) The structural style of sedimentary basins on the shelves of the Laptev Sea and western East Siberian Sea, Siberian Arctic. J Pet Geol 28:269-286

34. Franke D, Hinz K (2009) Geology of the shelves surrounding the New Siberian Islands, Russian Arctic. In: Stone DB, Fujita K, Layer PW, Miller EL, Prokopiev AV, Toro J (eds) Geology, geophysics and tectonics of Northeastern Russia: a tribute to Leonid Parfenov. Series 4. Copernicus GmbH, Göttingen, pp 35-44

35. Franke D, Hinz K, Oncken O (2001) The Laptev Sea rift. Mar Pet Geol 18:1083-1127

36. Franke D, Hinz K, Reichert Ch (2004) Geology of the East Siberian Sea, Russian Arctic, from seismic images: structures, evolution, and implications for the evolution of the Arctic Ocean Basin. J Geophys Res 109:1-19

37. Fujita K, Cook D (1990) The Arctic continental margin of eastern Siberia. In: Grantz A, Johnson L, Sweeney JF (eds) The Arctic Ocean region. The geology of North America, vol. L. Geological Society of America, Boulder, pp 257-288

38. Ganelin AV, Sokolov SD, Layer P, Simonov VA (2013) New isotopic age data on ophiolite complexes of western Chukotka (northeast Russia). Dokl Earth Sci 451:679-683

39. Gautier D, Bird K, Charpentier R, Grantz A, Houseknecht D, Klett T, Moore E (2009) Assessment of Undiscovered Oil and Gas in the Arctic. Science 324(5931):1175-1179

40. Gee DG, Kumpulainen R, Roberts D, Stephens MB, Thon A, Zachrisson E (1985) Scandinavian Caledonides, tectonostratigraphic map, scale 1:2,000,000. In: Gee DG, Sturt BA (eds) The Caledonide Orogen-Scandinavia and related areas. Wiley, Chichester

41. Gee DG, Sturt BA (eds) (1985) The Caledonide OrogenScandinavia and related areas. Wiley, Chichester

42. Gee DG, Pease V (eds) (2004) The Neoproterozoic Timanide Orogen of Eastern Baltica. Geological Society, London, Memoirs (30)

43. Gee DG, Bogolepova OK, Lorenz H (2006) The Timanide, Caledonide and Uralide orogens in the Eurasian high Arctic, and relationships to the palaeo-continents Laurentia, Baltica and Siberia. In: Gee DG, Stephenson RA (eds) European lithosphere of dynamics: Geological Society, London, Memoirs, 32, pp 507-521

44. Goryachev NA, Byalobzhesky SG, Salnikov AS, Akinin VV, Miller EL (2008) Crustal structure of Cretaceous accretionary orogenic belts of north-eastern Asia based on data from the 2DV geophysical transect: Eos (Transactions of the American Geophysical Union), vol 89, Fall Meeting supplement, abstract T13B-1945

45. Grachev AF (1983) Geodynamics of the transitional zone from the Moma Rift to the Gakkel Ridge. In: Watkins JS, Drake CL (eds) Studies in continental margin geology. Am Assoc Pet Geol Mem. 34:103-114

46. Gramberg IS, Ushakov VI (eds) (2000) Severnaya Zemlya. Geol Min Res. VNIIOkeangeologia, St Petersburg (in Russian)

47. Grantz A, Mann DM, May SD (1986) Multichannel seismicreflection data collected in 1978 in the eastern Chukchi Sea. US Geological Survey Open-File Report, pp 86-206
48. Grantz A, May SD, Hart PE (1990) Geology of the Arctic continental margin of Alaska. In: Grantz A, Johnson GL, Sweeney JF (eds) The Arctic Ocean region. The Geology of North America, L. Geological Society of America, Boulder, pp 257-288

49. Grantz A, Scott RA, Drachev SS, Moore TE, Valin ZC (2011) Sedimentary successions of the Arctic Region $\left(58-64^{\circ}\right.$ to $\left.90^{\circ} \mathrm{N}\right)$ that may be prospective for hydrocarbons. In: Spencer AM, Embry AF, Gautier DL, Stoupakova AV, Sørensen K (eds) Arctic petroleum geology. Geological Society (London) Memoirs, 35, pp 17-37

50. Gudlaugsson ST, Faleide JI, Johansen SE, Breivik AJ (1998) Late Palaeozoic structural development of the South-western Barents Sea. Mar Pet Geol 15:73-102

51. Harbert W, Frei L, Jarrard R, Halgedahl S, Engebretson D (1990) Palaeomagnetic and plate-tectonic constrains on the evolution of the Alaskan-eastern Siberian Arctic. In: Grantz A, Johnson GL, Sweeney JF (eds) The Arctic Ocean Region. The Geology of North America, L. Geological Society of America, Boulder, pp 567-592

52. Henriksen E, Ryseth AE, Larssen GB, Heide T, Rønning K, Sollid K, Stoupakova AV (2011) Tectonostratigrahy of the greater Barents Sea: implication for petroleum systems. In: Spencer AM, Embry AF, Gautier DL, Stoupakova AV, Sørensen K (eds) Arctic petroleum geology. Geological Society (London) Memoirs, 35, pp 163-195

53. Inger S, Scott RA, Golionko BG (1999) Tectonic evolution of the Taimyr Peninsula, northern Russia: implications for Arctic continental assembly. J Geol Soc Lond 156:1069-1072

54. Ivanov KS, Koroteev VA, Pecherkin MF, Fedorov YuN, Erokhin YuV (2009) The western part of the West Siberian petroleum megabasin: geologic history and structure of the basement. Russ Geol Geophys 50:365-379

55. Ivanov KS, Fedorov YuN, Ponomarev VS, Koroteev VA, Erokhin YuV (2012) Nature and age of metamorphic rocks from the basement of the West Siberian megabasin (according to U-Pb isotopic dates). Dokl Earth Sci 443(Issue 1):321-325

56. Ivanova NM, Sekretov SB, Shkarubo SI (1990) Geological structure of the Laptev Sea shelf according to seismic studies. Oceanology 29:600-604

57. Ivanova NM, Sakoulina TS, Roslov YuV (2006) Deep seismic investigation across the Barents-Kara region and Novozemelskiy Fold Belt (Arctic Shelf). Tectonophysics 420:123-140

58. Ivanova NM, Sakulina TS, Belyaev IV, Matveev YI, Roslov YV (2011) Depth model of the Barents and Kara seas according to geophysical surveys results. In: Spencer AM, Embry AF, Gautier DL, Stoupakova AV, Sørensen K (eds) Arctic Petroleum Geology. Geological Society (London) Memoirs, 35, pp 209-221

59. Jakobsson M, Mayer LA, Coakley B, Dowdeswell JA, Forbes S, Fridman B, Hodnesdal H, Noormets R, Pedersen R, Rebesco M, Schenke H-W, Zarayskaya Y, Accettella AD, Armstrong A, Anderson RM, Bienhoff P, Camerlenghi A, Church I, Edwards M, Gardner JV, Hall JK, Hell B, Hestvik OB, Kristoffersen Y, Marcussen C, Mohammad R, Mosher D, Nghiem SV, Pedrosa MT, Travaglini PG, Weatherall P (2012) The International Bathymetric Chart of the Arctic Ocean (IBCAO) version 3.0. Geophys Res Lett 39:L12609

60. Johansen SE, Ostisty BK et al (1993) Hydrocarbon potential in the Barents Sea region: play distribution and potential. In: Vorren TO, Bergsaker E, Dahl-Stamnes ØA, Holter E, Johansen B, Lie E, Lund TN (eds) Arctic geology and petroleum potential, Norwegian Petroleum Society special publication 2. Elsevier, Amsterdam, pp 273-320

61. Johansen SE, Henningsen T, Rundhovde E, Saether BM, Fichler C, Rueslåtten HG (1994) Continuation of the Caledonides north 
of Norway: seismic reflectors within the basement beneath the southern Barents Sea. Mar Pet Geol 11:190-201

62. Jokat W, Hegewald A, Kahlberg T, Kollofrath J, Kessling S, Martens H, Pulm P, Urlaub M, Winter F (2009) Marine Geophysics. In: Jokat W (ed) The expedition vessel "Polarstern" to the Arctic in 2008 (ARK-XXIII/3), Berichte zur Polar- und Meeresforschung (Reports on Polar and Marine Research), 597, pp 87-94

63. Kaminsky VD, Suprunenko OI, Suslova VV (2011) Oil and gas potential of the Russian Arctic Shelf and palaeogeographical mapping of the Barents Sea. In: Spencer AM, Embry AF, Gautier DL, Stoupakova AV, Sørensen K (eds) Arctic petroleum geology. Geological Society (London) Memoirs, 35, pp 345-352

64. Kaplan AA, Copeland P et al (2001) New radiometric ages of igneous and metamorphic rocks from the Russian Arctic. In: Abstracts of AAPG Regional Conference 2001. VNIGRI and AAPG, St Petersburg, 2001

65. Khain VE (2001) Tectonics of continents and oceans (Year 2000). Moscow, Nauchnyi Mir

66. Khain EV, Bibikova EV, Salnikova EB, Kröner A, Gibsher AS, Didenko AN, Degtyarev KE, Fedotova AA (2003) The PalaeoAsian ocean in the Neoproterozoic and Early Paleozoic: new geochronologic data and paleotectonic reconstructions. Precambrian Res 122:329-358

67. Khlebnikov PA, Belenky V, Peshkova IN, Kazanin GS, Shkarubo SI, Pavlov SP, Shlykova VV (2011) Geological structure and petroleum potential of the eastern flank of the Northern Barents Basin. In: Spencer AM, Embry AF, Gautier DL, Stoupakova AV, Sørensen K (eds) Arctic petroleum geology. Geological Society (London) Memoirs, 35, pp 261-269

68. Klemperer SL, Miller EL, Grantz A, Scholl DW, The BeringChukchi Working Group (2002) Crustal structure of the Bering and Chukchi Shelves: deep seismic reflection profiles across the North American continent between Alaska and Russia. In: Miller EL, Grantz A, Klemperer SL (eds) Tectonic evolution of the Bering Shelf-Chukchi Sea-Arctic Margin and adjacent landmasses. Geological Society of America, Boulder, Special Papers, 360, pp 1-24

69. Klitzke P, Faleide JI, Scheck-Wenderoth M, Sippel J (2015) A lithosphere-scale structural model of the Barents Sea and Kara Sea region. Solid Earth 6:153-172

70. Korago EA, Kovaleva GN, Lopatin BG, Orgo VV (2004) The Precambrian rocks of Novaya Zemlya. In: Gee DG, Pease VL (eds) The Neoproterozoic Timanide Orogen of eastern Baltica. Geological Society, London, Memoirs, 30, pp 135-143

71. Korago EA, Kovaleva GN et al (2009) To a problem of continental crust age on west of Eurasian Arctic (based on data from zircon geochronology from Ordovician and Silurian of northwestern Novaya Zemlya). In: Geology of Polar Regions of the Earth. Materials of XLII Tectonic Conference, I. GEOS, Moscow, pp 285-289 (in Russian)

72. Korago EA, Vernikovsky VA, Sobolev NN, Larionov AN, Sergeev SA, Stolbov NM, Proskurin VF, Sobolev PS, Metelkin DV, Matushkin NYu, Travin AV (2014) Age of the Basement beneath the De Long Islands (New Siberian Archipelago): new geochronological data. Dokl Earth Sci 457(Part):803-809

73. Kos'ko M (1994) Major Tectonic Interpretations and Constraints for the New Siberian Islands Region, Russian Arctic. Proceedings International Conference on Arctic Margins, Anchorage, AK, September 1992. US Department of the Interior, Minerals Management, pp 195-200

74. Kos'ko MK, Trufanov GV (2002) Middle Cretaceous to Eopleistocene sequences on the New Siberian Islands: an approach to interpret offshore seismic. Mar Pet Geol 19:901-919
75. Kos'ko MK, Lopatin BG, Ganelin VG (1990) Major geological features of the islands of the East Siberian and Chukchi Seas and the northern coast of Chukotka. Mar Geol 93:349-367

76. Kos'ko MK, Cecile MP, Harrison JC, Ganelin VG, Khandoshko NV, Lopatin BG BG (1993) Geology of Wrangel Island, between Chukchi and East Siberian Seas. Northeastern Russia, Geological Survey of Canada, Ottawa, Bulletin (461)

77. Kos'ko MK, Sobolev NN, Korago EA, Proskurnin VF, Stolbov NM, Proskurnin VF, Stolbov NM (2013) Geology of New Siberian Islands-a basis for interpretation of geophysical data on the Eastern Arctic shelf of Russia. Neftegazovaya geologiya. Teor I Prakt 8(No. 2):1-36 (in Russian)

78. Kuzmichev AB (2009) Where does the South Anyui suture go in the New Siberian Islands and Laptev Sea? Implications for the Amerasia basin origin. Tectonophysics 463:86-108

79. Kuzmichev AB, Pease V (2007) Siberian trap magmatism on the New Siberian Islands: constraints for east Arctic Mesozoic plate tectonic reconstructions. J Geol Soc Lond 164:959-968

80. Kuznetsov NB (2006) The Cambrian Baltica-Arctida collision, pre-Uralide-Timanide orogen, and its erosion products in the Arctic. Dokl Earth Sci 411A(9):1375-1380. doi:10.1134/ S1028334X06090091

81. Kuznetsov NB, Soboleva AA, Udoratina OV, Gertseva OV, Andreichev VL (2007) Pre-Ordovician tectonic evolution and volcano-plutonic associations of the Timanides and northern Pre-Uralides, northeast part of the East European Craton. Gondwana Res 12:305-323

82. Kuznetsov NB, Natapov LM, Belousova EA, O'Reilly SY, Griffin WL (2010) Geochronological, geochemical and isotopic study of detrital zircon suites from late Neoproterozoic clastic strata along the NE margin of the East European Craton: implications for plate tectonic models. Gondwana Res 17:583-601

83. Kuznetsov NB, Alekseev AS, Belousova EA, Romanyuk TV, Reimers AN (2015) First results of U/Pb isotope dating (LAICP-MS) of Detrital Zircons from sandstones of the low Cambrian brusov formation of the southeastern White Sea Region: a constraint for the lower age limit of the beginning of the Arctida-Baltica collision. Dokl Earth Sci 460(Part 1):28-32

84. Lane LS (2007) Devonian-Carboniferous paleogeography and orogenesis, northern Yukon and adjacent Arctic Alaska. Can J Earth Sci 44:679-694

85. Lawver LA, Gahagan LM, Norton I (2011) Palaeogeographic and tectonic evolution of the Arctic region during the Paleozoic. In: Spencer AM, Embry AF, Gautier DL, Stoupakova AV, Sørenson K (eds) Arctic Petroleum Geology. Geological Society, London, Memoirs, vol 35, pp 61-77

86. Lopatin BG, Pavlov LG, Orgo VV, Shkarubo SI (2001) Tectonic structure of Novaya Zemlya. Polarforschung 69:131-135

87. Lopatin BG (ed) (2012) State geological map of the Russian Federation. Scale 1:1,000,000 (new series). South Kara Series, Sheet R-41, Amderma. Explanatory Note. St. Petersburg, VSEGEI (in Russian)

88. Lorenz H, Gee DG, Bogolepova OK (2006) Early Palaeozoic unconformity on Severnaya Zemlya and relationships to the Timanian margin of Baltica. In: Scott RA, Thurston DK (eds) Proceedings of the Fourth International Conference on Arctic Margins, Dartmouth, Nova Scotia, 30 September to 3 October 2003. US Department of the Interior, Anchorage, pp 14-30

89. Lorenz H, Gee DG, Whitehouse MJ (2007) New geochronological data on Palaeozoic igneous activity and deformation in the Severnaya Zemlya Archipelago, Russia, and implications for the development of the Eurasian Arctic margin. Geol Mag 144:105-125

90. Lorenz H, Männik P, Gee DG, Proskurnin V (2008) Geology of the Severnaya Zemlya Archipelago and the North Kara Terrane 
in the Russian high Arctic. Int J Earth Sci (Geol Rundsch), 97:519-547

91. Makar'ev AA (ed) (2013) State geological map of the Russian Federation. Scale 1:1 000,000 [third generation]. Sheet T45-48. Cheliuskin. A.P. Karpinskij Russian Geological Research Institute, St. Petersburg

92. Malyshev NA, Nikishin VA, Nikishin AM, Obmetko VV, Martirosyan VN, Kleshchina LN, Reydik YuV (2012) A new model of the geological structure and evolution of the North Kara sedimentary basin. Dokl Earth Sci 445:791-795

93. Malyshev NA, Nikishin VA, Nikishin AM, Obmetko VV, Kleshchina LN (2013) The Ordovician Urvantsev Evaporite basin in the northern part of the Kara Sea. Dokl Earth Sci 448:157-160

94. Marello L, Ebbing J, Gernigon L (2013) Basement inhomogeneities and crustal setting in the Barents Sea from a combined 3D gravity and magnetic model. Geophys J Int 193:557-584

95. Metelkin DV, Vernikovsky VA, Kazansky AYu, Bogolepova OK, Gubanov AP (2005) Palaeozoic history of the Kara microcontinent and its relation to Siberia and Baltica: paleomagnetism, paleogeography and tectonics. Tectonophysics 398:225-243

96. Miller E, Verzhbitsky V (2009) Structural studies near Pevek, Russia: implications for formation of the East Siberian Shelf and Makarov Basin of the Arctic Ocean. Geology, Geophysics and Tectonics of Northeastern Russia: a tribute to L. Parfenov, pp 1-19

97. Miller EL, Katkov SM, Strickland A, Toro J, Akinin VV, Dumitru TA (2009) Geochronology and thermochronology of Cretaceous plutons and metamorphic country rocks, AnyuiChukotka fold belt, North East Arctic Russia. Stephan Mueller Spec Publ Ser 4:157-175

98. Miller EL, Gehrels GE, Pease V, Sokolov S (2010) Stratigraphy and $\mathrm{U}-\mathrm{Pb}$ detrital zircon geochronology of Wrangel Island, Russia: implications for Arctic paleogeography. AAPG Bull 94:665-692

99. Moore TE,Wallace WK, Bird KJ, Karl SM, Mull CG, Dillon JT (1994) Geology of northern Alaska. In: Plafker G, Berg HC (eds) The geology of Alaska. The Geology of North America, G-1. Geological Society of America, Boulder, pp 49-140

100. Moore TE, Dumitru TA, Adams KE, Witebsky SN, Harris AG (2002) Origin of the Lisburne Hills-Herald Arch structural belt: stratigraphic, structural, and fission track evidence from the Cape Lisburne area, northwestern Alaska. In: Miller EL, Grantz A, Klemperer SL (eds) Tectonic evolution of the Bering ShelfChukchi Sea-Arctic margin and adjacent landmasses. Geological Society of America Special Paper, Boulder, 360, pp 77-109

101. Moore TE, O'Sullivan PB, Potter CJ, Donelick RA (2015) Provenance and detrital zircon geochronologic evolution of lower Brookian foreland basin deposits of the western Brooks Range, Alaska, and implications for early Brookian tectonism. Geosphere 11(1):93-122

102. Natal'in BA, Amato JM, Toro J, Wright JE (1999) Paleozoic rocks of Northern Chukotka Peninsula, Russian Far East: implications for the tectonics of the Arctic Region. Tectonics 18:977-1003

103. Nikishin A, Amelin N, Petrov E, Miles L, Semb PH, Lie O, Dahl N (2013) New 2D seismic data improve evaluation of Barents and Kara Sea basins. World Oil 234(11):77-80

104. Nikishin VA, Malysgev NA, Nikishin AM, Obmetko VV (2011) Late Permian-Triassic rift system of the South Kara sedimentary basin. Vestnik Moskovskogo Universiteta, Seriya. 4(No. 6):3-9

105. Nikishin VA (2013) Intrabasinal and basin-margin deformations in sedimentary basins of the Kara Region. PhD Thesis. Moscow State Unifersity, Geological Department

106. Nokleberg WJ, Parfenov LM (2001) Phanerozoic tectonic evolution of the Circum-North Pacific. US Geological Survey, Reston, VA, Professional Papers, 1626
107. Nokleberg WJ (ed) (2010) Metallogenesis and tectonics of northeast Asia. US Geological Survey Professional Paper, 1765

108. Oxman VS (2003) Tectonic evolution of the Mesozoic Verkhoyansk-Kolyma belt (NE Asia). Tectonophysics 365:45-76

109. Parfenov LM (1991) Tectonics of the Verkhoyansk-Kolyma Mesozoides in the context of plate tectonics. Tectonophysics 199:319-342

110. Parfenov LM, Natal'in BA (1986) Mesozoic tectonic evolution of northeastern Asia. Tectonophysics 127:291-304

111. Parfenov LM, Kuz'min MI (eds) (2001) Tectonics, geodynamics and metallogeny of the Sakha Republic (Yakutia). MAIK "Nauka/Interperiodica", Moscow (in Russian)

112. Parfenov LM, Natapov LM, Sokolov SD, Ttsukanov NV (1993) Terrane analysis and accretion in northeast Asia. Isl Arc 2:35-54

113. Parfenov LM, Prokopiev AV, Gaiduk VV (1995) Cretaceous frontal thrusts of the Verkhoyansk fold belt, eastern Siberia. Tectonics 4:342-358

114. Patrick BE, McClelland WC (1995) Late Proterozoic granitic magmatism on Seward Peninsula and a Barentian origin for Arctic Alaska-Chukotka. Geology 23:81-84

115. Pease V (2011) Eurasian orogens and Arctic tectonics: an overview. In: Spencer AM, Embry AF, Gautier DL, Stoupakova AV, Sørensen K (eds) Arctic petroleum geology. Geological Society (London) Memoirs, 35, pp 311-324

116. Pease V, Scott RA (2009) Crustal affinities in the Arctic Uralides, northern Russia: significance of detrital zircon ages from Neoproterozoic and Paleozoic sediments in Novaya Zemlya and Taimyr. J Geol Soc Lond 166:517-527

117. Pease V, Gee D, Lopatin B (2001) Is Franz Josef Land affected by Caledonian deformation? Eur Union Geosci Abstr 5:757

118. Pease V, Gee D, Vernikovsky V, Vernikovskaya A, Kireev S (2001) Geochronological evidence for late-Grenvillian magmatic and metamorphic events in central Taimyr, northern Siberia. Terra Nova 13(4):270-280

119. Pease V, Daly JS et al (2008) Baltica in the Cryogenian, 850-630 Ma. Precambrian Res 160:48-65

120. Pease VL, Kuzmichev AB, Danukalova MK (2014) The New Siberian Islands and evidence for the continuation of the Uralides, Arctic Russia. J Geol Soc 172:1-4

121. Peron-Pinvidic G, Manatschal G (2010) From microcontinents to extensional allochthons: witnesses of how continents break apart? Pet Geosci 16:189-197

122. Petrovskaya NA, Trishkina CV, Savishkina MA (2008) Main geological features of the Russian Chukchi Sea. Oil Gas Geol 6:20-28 (in Russian)

123. Pogrebitskiy YE (ed) (2004) Novaya Zemlya and Vaigach Island. Geological structure and Miragenia, 205. NIIGAVNIIOkeangeologiya, St Petersburg (in Russian)

124. Pol'kin YI (1984) Chukchi Sea. In: Gramberg IS, Pogrebitskiy YE (eds) Geological structure of the USSR and trends in distribution of mineral resources, 9, Seas of the Soviet Arctic. Nedra, Leningrad, pp 67-77 (in Russian)

125. Poselov VA, Butsenko VV, Kaminsky VD, Sakulina TS (2012) Mendeleev rise (Arctic Ocean) as a geological continuation of the continental margin of eastern Siberia. Dok Earth Sci 443:388-391

126. Prishchepa OM (2011) New ideas about tectonics and petroleum geology of the Timan-Pechora hydrocarbon province. Neftegazovaya Geologiya. Teoriya I Prakt. 6(\#4):15-30 (in Russian)

127. Prishchepa OM, Bazhenova TK, Bogatskii VI (2011) Petroleum systems of the Timan-Pechora sedimentary basin (including the offshore Pechora Sea). Russ Geol Geophys 52:888-905

128. Prokopiev A, Ershova V, Anfinson O, Khudoley A, Vasiliev D, Stockli D (2015) Tectonics of New Siberia islands: structural 
styles and Zircon U-Th/He ages. In: AAPG 3P Arctic conference abstract volume. Stavanger, pp 74-75

129. Proskurnin VF (1999) About angular unconformities in upper Pre-Cambrian and lower Palaeozoic of the Severnaya Zemlya Archipelago. In: Simonov ON (ed) Taimyr's Subsoil. Collection of the Papers. VSEGEI, Taimyrkomprirodresursy, Norilsk, pp 68-76 (in Russian)

130. Puchkov VN (1997) Structure and geodynamics of the Uralian Orogen. In: Burg J-P, Ford M (eds) Orogeny through time. Geological Society, London, Special Publications, 121, pp 201-234

131. Puchkov V (2002) Paleozoic evolution of the East European continental margin involved into the Urals. In: Brown D, Juhlin C, Puchkov V (eds) Mountain building in the Uralides: Pangea to the present. AGU Geophysical Monograph Series, vol 132, pp 9-31

132. Puchkov VN (2005) Evolution of the lithosphere from the Pechora Ocean to Timan Orogen and from Uralian Paleocean to Uralian Orogen. In: Leonov MG (ed) Problems of the Central Asia tectonics. GEOS, Moscow, pp 309-342 (in Russian)

133. Puchkov VN (2009) The evolution of the Uralian orogeny. In: Murphy JB, Keppie JD, Hynes AJ (eds) Ancient Orogens and modern analogues. Geological Society, London, Special Publications, 327, pp 161-195

134. Ritzmann O, Faleide JI (2007) The Caledonian basement of the western Barents Sea. Tectonics, 26:TC5014. doi:10.1029/ 2006TC002059

135. Sakoulina TS, Telegin AN, Tikhonova IM, Verba ML, Matveev YuI, Vinnick AA, Kopylova AV, Dvornikov LG (2000) The results of deep seismic investigations on geotraverses in the Barents Sea from Kola Peninsula to Franz-Josef Land. Tectonophysics 329:319-331

136. Sakoulina TS, Verba ML, Kabushina TB, Krupnova NA, Tabyrtsa SN, Ivanov GI (2011) Integrated geological-geophysical investigations along a reference line 5-AR in the East Siberian Sea. Razved I Okhrana Nedr 10:17-23

137. Savostin LA, Karasik AM (1981) Recent plate tectonics of the Arctic basin and of northeastern Asia. Tectonophysics 74:111-145

138. Savostin LA, Natapov LM, Stavsky AP (1984) Mesozoic palaeogeodynamics and palaeogeography of the Arctic region. In: 27th International Geological Congress (Moscow), Arctic geology. Reports, 4. Nauka, Moscow, pp 217-237

139. Scarrow JH, Pease V, Fleutelot C, Dushin V (2001) The Late Proterozoic Enganepe ophiolite, Polar Urals, Russia: an extension of the Cadomian arc? Precambrian Res 110:255-275

140. Scarrow JH, Hetzel R et al (2002) Four decades of geochronological work in the southern and middle Urals: a review. In: Brown D, Juhlin C, Puchkov V (eds) Mountain building in the Uralides: Pangea to present, Geophysical Monographs. AGU, Washington, DC, 132, pp 233-256

141. Schenk CJ (2011) Geology and petroleum potential of the Timan-Pechora Basin Province, Russia. In: Spencer AM, Embry AF, Gautier DL, Stoupakova AV, Sørensen K (eds) Arctic petroleum geology. Geological Society (London) Memoirs, 35, pp 283-294

142. Scott RA, Howard JP, Guo L, Schekoldin R, Pease V (2010) Offset and curvature of the Novaya Zemlya fold-and-thrust belt, Arctic Russia. In: Vining BA, Pickering SC (eds) Petroleum geology: from mature basins to new frontiers. In: Proceedings of the 7th petroleum geology conference. Geological Society, London, pp 645-647

143. Sekretov SB (2000) Petroleum potential of the Laptev Sea basins: geological, tectonic and geodynamic factors. In: Roland NW, Tessensohn F (eds) III international conference on Arctic Margins. Polarforschung, 68, pp 179-186
144. Şengör AMC (1984) The Cimmeride orogenic system and the tectonics of Euraisa. GSA Special Papers, vol 195, pp 1-74

145. Shephard GE, Müller DR, Seton M (2013) The tectonic evolution of the Arctic since Pangea breakup: integrating constraints from surface geology and geophysics with mantle structure. Earth Sci Rev 124:148-183

146. Shipilov EV, Tarasov GA (1998) Regional geology of oil and gas bearing sedimentary basins of the Russian West-Arctic Shelf. Kola Science Centre of Russian Academy of Sciences, Apatity (in Russian)

147. Shkarubo SI, Zavarzina GA (2011) Stratigraphic characteristics of seismic sequences in the sedimentary cover of the western Laptev Sea shelf. Neftegazovaya geologiya. Teor Prakt 6(2):1-21 (in Russian)

148. Shkarubo SI, Zavarzina GA, Zuikova ON (2014) Results of modern stage of the Laptev Sea shelf study: from hypotheses to new facts and challenges. Okhrana Razvedka Nedr 4:23-30 (in Russian)

149. Skorobogatov VA, Stroganov LV, Kopeev VD (2003) Geological structure and hydrocarbon potential of Yamal Peninsula. Nedra, Moscow (in Russian)

150. Smelror M, Petrov OV, Larssen GB, Werner S (eds) (2009) Geological History of the Barents Sea Atlas. Geological Survey of Norway, Trondheim (136 p)

151. Sokolov SD (2010) Tectonics of Northeast Asia: an overview. Geotectonics 2010(44):493-509

152. Sokolov SD, Bondarenko GY et al (2002) South Anyui suture, northeast Arctic Russia: facts and problems. In: Miller EL, Grantz A, Klemperer SL (eds) Tectonic evolution of the Bering Shelf-Chukchi Sea-Arctic Margin and adjacent landmasses. Geological Society of America, Boulder, Special Papers, 360, pp 209-224

153. Sokolov SD, Bondarenko GY, Layer PW, Kravchenko-Berezhnoy IR (2009) South Anyui suture: tectono-stratigraphy, deformations, and principal tectonic events. In: Stone DB, Fujita K, Layer PW, Miller EL, Prokopiev AV, Toro J (eds) Geology, geophysics and tectonics of northeastern Russia: a tribute to Leonid Parfenov Series 4. Copernicus GmbH, Göttingen, pp 201-221

154. Sokolov SD, Tuchkova MI, Ganelin AV, Bondarenko GE, Layer P (2015) Tectonics of the South Anyui suture, northeastern Asia. Geotectonics 49:3-26

155. Stoupakova AV, Henriksen E, Burlin YK, Larsen GB, Milne JK, Kiryukhina TA, Golynchik PO, Bordunov SI, Ogarkova MP, Suslova AA (2011) The geological evolution and hydrocarbon potential of the Barents and Kara shelves. In: Spencer AM, Embry AF, Gautier DL, Stoupakova AV, Sørensen K (eds) Arctic petroleum geology. Geological Society (London) Memoirs, 35, pp 325-344

156. Sullivan MA, Creaney S et al (2007) Hydrocarbon system framework of Russia: pre-cambrian to present-day. In: International AAPG Conference, Athens, Greece, pp 19-27 November. Abstracts

157. Surkov VS, Kazakov AM, Devyatkov VP, Smirnov VL (1997) Lower-Middle Triassic rift sequence of the West Siberian basin. Otechestvennaya Geol 3:31-37 (in Russian)

158. Timonin NI, Yudin VV, Belyaev AA (2004) Paleogeodynamics of Pai-Khoi. Yekatirnburg, Uralian branch of RAS (226 p)

159. Tolson RB (1987) Structure and stratigraphy of the Hope Basin, Southern Chukchi Sea, Alaska. In: Scholl DW, Grantz A, Vedder JG (eds) Geology and resource potential of the continental margin of western North America and adjacent ocean basins; Beaufort Sea to Baja California. Earth Sciences Series. Circum-Pacific Council for Energy and Mineral Resources, 6, Houston, pp 59-72

160. Toro J, Miller EL, Prokopiev AV, Zhang X, Veselovskiy R (2015) Mesozoic orogens of the Arctic. In: Pease V, Coakley B, 
Barbante C, Jordan P (eds) Emerging Questions in Arctic Geoscience. Special Publication, Geological Society of London (in press)

161. Uflyand AK, Natapov LM, Lopatin VM et al (1991) About tectonic nature of Taimyr. Geotektonika 6:76-93 (in Russian)

162. Ustritsky VI (1989) On the tectonic origin of the Barents-North Kara Megabasin. In: Problems of petroleum geology of the World Ocean. Moscow. Nedra, Leningrad, pp 182-191 (in Russian)

163. Vernikovsky VA, Neimark LA, Ponomarchuk VA, Vernikovskaya AE, Kireev AD, Kuzmin DS (1995) Geochemistry and age of collision granitoids and metamorphites of the Kara microcontinent (Northern Taimyr). Russ Geol Geophys 36:46-60

164. Vernikovsky VA (1996) The geodynamic evolution of the Taimyr folded area. Geol Pac Ocean 12:691-704

165. Vernikovsky VA, Sal'nikova EB, Kotov AB, Ponomarchuk VA, Kovach VP, Travin AV (1998) Age of postcollision granitoids, North Taimyr: U-Pb, Sm-Nd, Rb-Sr and Ar-Ar data. Dokl RAN 363:375-378 (in Russian)

166. Vernikovsky V, Vernikovskaya A (2001) Central Taimyr accretionary belt (Arctic Asia): meso-neoproterozoic tectonic evolution and Rodinia breakup. Precambrian Res 110:127-141

167. Vernikovsky VA, Pease V, Vernikovskaya AE, Romanov AP, Gee DG, Travin AV (2003) First report of early Triassic A-type granite and syenite intrusions from Taimyr: product of the northern Eurasian superplume? Lithos 66(1-2):23-36

168. Vernikovsky VA, Metelkin DV, Tolmacheva TYu, Malyshev NA, Petrov OV, Sobolev NN, Matushkin NYu (2013) Concerning the Issue of Paleotectonic Reconstructions in the Arctic and of the Tectonic Unity of the New Siberian Islands Terrane: new paleomagnetic and paleontological data. Dokl Earth Sci 451(Part 2):791-797

169. Vernikovsky VA, Dobretsov NL, Metelkin DV, Matushkin NYu, Koulakov IYu (2013) Concerning tectonics and the tectonic evolution of the Arctic. Russ Geol Geophys 54:838-858

170. Verzhbitsky V, Frantzen EK, Trommestad K, Savostina T, Little A, Sokolov SD, Tuchkova MI, Travis T, Martyntsiva O, Ullnaess M (2008) New seismic data on the South and North Chukchi sedimentary basins and the Wrangel Arch and their significance for the geology of Chukchi Sea shelf (Russian Arctic). In: Proceedings of the EAGE 3rd St Petersburg International Conference and Exhibition, St Petersburg
171. Verzhbitsky VE, Murzin RR, Vasilyev VE, Malysheva SV, Ananyev VV, Komissarov DK, Roslov YuV (2011) New look at the seismic stratigraphy and hydrocarbon systems of Paleozoic sedimentary rocks of North Kara shelf. Neft Khozyaistvo 12:18-21 (in Russian)

172. Verzhbitsky VE, Kosenkova N, Ananyev V, Malysheva S, Vasilyev V, Murzin R, Komissarov D, Roslov Yu (2012) Geology and hydrocarbon potential of Kara Sea. Oil Gas J 1-2:48-54 (in Russian)

173. Verzhbitsky VE, Sokolov SD, Frantzen EM, Little A, Tuchkova MI, Lobkovsky LI (2012b) The South Chukchi Sedimentary Basin (Chukchi Sea, Russian Arctic): age, structural pattern, and hydrocarbon potential. In: Gao D (ed) Tectonics and sedimentation: implications for petroleum systems. AAPG Memoir, 100, pp 267-290

174. Verzhbitsky VE, Sokolov SD, Tuchkova MI (2015) Present-day structure and stages of tectonic evolution of Wrangel Island, Russian Eastern Arctic Region. Geotectonics 49(No. 3):165-192

175. Vyssotski AV, Vyssotski VN, Nezhdanov AA (2006) Evolution of the West Siberian Basin. Mar Pet Geol 23:93-126

176. Walderhaug HJ, Eide EA, Scott RA, Inger S, Golionko EG (2005) Palaeomagnetism and 40Ar/39Ar geochronology from the South Taimyr igneous complex, Arctic Russia: a MiddleLate Triassic magmatic pulse after Siberian flood-basalt volcanism. Geophys J Int 163:501-517

177. Worsley D (2008) The post-Caledonian development of Svalbard and the western Barents Sea. Polar Res 27:298-317

178. Zavarzina GA, Shkarubo SI, Shlykova VV, Poshtatskaya AG (2014) New data on tectonics of the Pritaimyr Shelf, Laptev Sea. Okhrana I Razvedka Nedr 4:31-34 (in Russian)

179. Zhang X, Omma J, Pease V, Scott R (2013) Provenance of Late Paleozoic-Mesozoic Sandstones, Taimyr. Peninsula, the Arctic. Geosciences 3:502-527

180. Zonenshain LP, Korinevsky VG, Kazmin VG, Matveenkov VV, Khain VV (1984) Plate tectonic model for the development of the south Urals. Tectonophysics 109:95-135

181. Zonenshain LP, Kuzmin MI, Natapov LM (1990) Geology of the USSR: a plate tectonic synthesis, Geodynamics Series. AGU, Washington, DC (21) 